\title{
KOŚCIÓŁ W OPATOWIE W WARUNKACH KOMUNIZMU (1945-1966)
}

\section{Wstęp}

Artykuł ma na celu przedstawienie niektórych elementów świadczących o kondycji Kościoła rzymskokatolickiego w Opatowie w pierwszych dwóch dekadach ustroju komunistycznego w Polsce. Przyjęte cezury wynikają z kilku powodów. Wydarzenia z 1945 r. i 1966 r. stanowią przełomowe momenty dla władz państwowych oraz kościelnych, zarówno w ich odrębnych dziejach jak i wzajemnych relacjach. Zakończenie II wojny światowej dało początek zmianom systemu politycznego w Polsce i spowodowało, że Kościół katolicki w Polsce znalazł się w nowych, bardzo trudnych warunkach. Dwadzieścia lat uprawiania z różnym natężeniem polityki antykościelnej władz komunistycznych i obrony wolności religii przez Kościół zaowocowało swoistym apogeum napięcia tj. konfrontacją w roku Milenium Chrztu Polski ${ }^{1}$. Przyjęcie zamykającej cezury w 1966 r. jest uzasadnione chęcią zachowania większej odległości czasowej do opisywanych faktów. Wydaje się, że dystans prawie pół wieku przekonuje przeciwników prowadzenia badań historycznych wobec współczesności. Argumentem jest też ograniczona możliwość dostępu do części najnowszych materiałów archiwalnych. W tekście wykorzystano zasadniczo archiwalia proweniencji kościelnej oraz dokumentację państwowej administracji do spraw wyznań. Informacje zawarte w aktach aparatu bezpieczeństwa zaczerpnięto głównie z tekstu Roksany Szczypty-Szczęch ${ }^{2}$ oraz dwutomowej monografii ks. Bogdana Stanaszka ${ }^{3}$.

1 Warto w tym miejscu skierować uwagę Czytelników na dostępne syntezy dotyczące najnowszych dziejów Kościoła katolickiego w Polsce oraz relacji między państwem a Kościołem w czasach PRL. A. Dudek, R. Gryz, Komuniści i Kościół w Polsce (19451989), Kraków 2006; Z. Zieliński, Kościół w Polsce 1944-2002, Radom 2003; J. Żaryn, Dzieje Kościoła katolickiego w Polsce (1944-1989), Warszawa 2003.

2 R. Szczypta-Szczęch, Powiatowy Urząd Bezpieczeństwa Publicznego Opatów z siedziba w Ostrowcu Świętokrzyskim wobec Kościoła katolickiego w latach 1945-1955, w: Aparat represji wobec Kościoła w latach 1944-1956, terytorium obecnej diecezji sandomierskiej, red. M. Krzysztofiński, ks. J. Marecki, ks. B. Stanaszek, Kraków 2012, s. 49-140.

3 B. Stanaszek, Diecezja sandomierska w powojennej rzeczywistości politycznej w latach 1945-1967, t. 1, Problematyka personalno-organizacyjna, Sandomierz 2006; B. Stanaszek, Diecezja sandomierska w powojennej rzeczywistości politycznej w latach 1945-1967, t. 2, Duszpasterstwo i laicyzacja życia społecznego, Sandomierz 2006. 


\section{Kościelny stan posiadania}

Od zakończenia II wojny światowej do połowy lat sześćdziesiątych miasto Opatów przeżywało demograficzną stagnację. Wymordowanie Żydów przez Niemców podczas wojny spowodowało ujednolicenie wyznaniowe i jednocześnie spadek liczby mieszkańców z niemal 10 tys. w 1931 r. do około 5,5 tys. w 1946 r. Następnie w 1950 r. regres sięgnął dna - czyli liczby 4,5 tys. mieszkańców. W 1960 r. ludność miasta wzrosła do 5,7 tys., a w 1965 r. do nieco ponad 5,8 tys. Ta sytuacja związana była z brakiem przemysłu w mieście i rolniczym charakterem powiatu opatowskiego (wzrost z 12 do 31 osób zatrudnionych w przemyśle na 1000 mieszkańców) ${ }^{4}$. Sytuacja ta miała swe przełożenie na liczbę wiernych w dekanacie opatowskim. Ujemny bilans migracji spowodował jej obniżenie z 37,6 tys. w 1946 r. do 31,3 tys. w 1964 r. ${ }^{5}$ W opatowskiej parafii św. Marcina Biskupa liczba wiernych zachowała pewne status quo i wahała się wokół 8 tysięcy ludzi (od 8010 w 1945 r. do 7957 osób w 1958 r.) $)^{6}$. Spadek liczby wiernych w parafii w Opatowie w 1958 r. związany był z erygowaniem nowej - dwunastej parafii w dekanacie opatowskim. Była to parafia Biskupice, która objęła swym zasięgiem kilka miejscowości wchodzących wcześniej do parafii w Opatowie (Bełcz, Biskupice, Bukowiany, Czekaj, Łężyce Michałów i Niemienice)7. Liczba katolików w wiejskich parafiach dekanatu opatowskiego zmalała w jeszcze większym zakresie niż w Opatowie. Podane w rocznikach diecezji sandomierskiej wielkości (tab. 1) należy postrzegać jako szacunkowe, ale wystarczające do ukazania występującego wyraźnie trendu spadkowego.

4 „Województwo kieleckie w liczbach 1961-1965”, 5 (1966), s. 11, 127-128; K. Fedorowski, Represje Powiatowego Urzędu Bezpieczeństwa Publicznego w Sandomierzu wobec Kościoła rzymskokatolickiego w latach 1944-1956 - problematyka personalno-organizacyjna, „Studia Sandomierskie” 19 (2012), nr 1, s. 8.

5 B. Stanaszek, Diecezja sandomierska..., dz. cyt., t. 1, s. 78.

6 Spis Duchowieństwa i parafij Diecezji Sandomierskiej 1944-1945 r., Sandomierz 1945, s. 41; Spis Duchowieństwa i parafij Diecezji Sandomierskiej 1946 r., Sandomierz 1946, s. 49; Rocznik diecezji sandomierskiej 1948 r., Sandomierz 1948, s. 60-64; Rocznik diecezji sandomierskiej 1952/53 r., Sandomierz 1953, s. 55-58; Rocznik diecezji sandomierskiej 1958 r., Sandomierz 1958, s. 65-70. Dane z lat 1945 i 1946 nie są miarodajne. W porównaniu z przedwojenną edycją tego źródła widzimy, że nie zaktualizowano liczby parafian. Spis z 1939 roku także podawał liczbę 8010 katolików. Różnica występuje tylko w przypadku parafii Ptkanów, ale najprawdopodobniej jest to błąd w druku. Słowem dane z pierwszych powojennych lat nie były aktualizowane w stosunku do schyłku okresu międzywojennego. Spis... 1946 r., dz. cyt., s. 49; por: Spis Duchowieństwa i parafij Diecezji Sandomierskiej 1939, Sandomierz 1939, s. 102.

7 Spis... 1939, dz. cyt., s. 102; Rocznik... 1958 r., dz. cyt., s. 65. 
Tabela 1. Katolicy w parafiach dekanatu opatowskiego w latach 1945-1958

\begin{tabular}{|l|l|c|c|c|c|}
\hline Lp. Lata & $\mathbf{1 9 4 5}$ & $\mathbf{1 9 4 8}$ & $\mathbf{1 9 5 2}$ & $\mathbf{1 9 5 8}$ \\
\hline 1. & Biskupice $^{8}$ & & & & 1435 \\
\hline 2. & Gierczyce & 1309 & 1234 & 1230 & 1210 \\
\hline 3. & Iwaniska & 6174 & 5667 & 6000 & 6007 \\
\hline 4. & Malice & 3972 & 3451 & 3632 & 3200 \\
\hline 5. & Modliborzyce & 2515 & 1864 & 1825 & 2021 \\
\hline 6. & Mydłów & 3083 & 2788 & 2450 & 2445 \\
\hline 7. & Opatów & $\mathbf{8 0 1 0}$ & $\mathbf{8 2 7 8}$ & $\mathbf{8 1 5 0}$ & $\mathbf{7 9 5 7}$ \\
\hline 8. & Ptkanów & 2830 & 2900 & 2260 & 2021 \\
\hline 9. & Ruszków & 1917 & 1773 & 1650 & 1600 \\
\hline 10. & Strzyżowice & 2421 & 1570 & 1500 & 1515 \\
\hline 11. & Włostów & 3009 & 1701 & 1651 & 1680 \\
\hline 12. & Wszechświęte & 2400 & 2200 & 1981 & 1939 \\
\hline & R a z e m & $\mathbf{3 9 6 4 0}$ & $\mathbf{3 3 4 3 5}$ & $\mathbf{3 2 3 2 9}$ & $\mathbf{3 3 0 0 0}$ \\
\hline
\end{tabular}

Źródło: Spis Duchowieństwa i parafij Diecezji Sandomierskiej 1944-1945 r., Sandomierz 1945, s. 4043; Rocznik diecezji sandomierskiej 1948 r., Sandomierz 1948, s. 60-64; Rocznik diecezji sandomierskiej 1952/53 r., Sandomierz 1953, s. 55-58; Rocznik diecezji sandomierskiej 1958 r., Sandomierz 1958, s. $65-70$.

W przedstawianym okresie liczba parafii w Opatowie nie zmieniła się?. Do jedynej parafii św. Marcina należały oprócz Opatowa okoliczne wioski: Adamów, Bełcz, Biskupice, Bukowiany, Czekaj, Czerników, Jałowęsy, Jurkowice, Karsy, Łężyce, Łyżka, Marcinkowice, Michałów, Niemienice, Oficjałów, Okalina, Opatów, Pobroszyn, Porudzie, Tomaszów, Wąworków, Wrzos, Zochcin ${ }^{10}$. Po reorganizacji dekanatu opatowskiego w 1957 r. parafia św. Marcina obejmowała oprócz Opatowa następujące miejscowości: Adamów, Czerników, Jałowęsy, Jurkowice, Karsy, Marcinkowice, Oficjałów, Okalina, Pobroszyn, Tomaszów, Wąworków, Zochcin Kolonia i Zochcin Wieś. Miejscowości te oddalone były od kościoła parafialnego od 2 do $5 \mathrm{~km}^{11}$. Oznacza to, że sytuacja duszpasterska była tu bardzo dobra. Parafia św. Marcina należała do diecezji sandomierskiej, która obejmowała w 1945 r. 240 parafii (12 kościołów filialnych), zaś w 1960 r. 266 parafii (4 ekspozytury) ${ }^{12}$.

Po zakończeniu II wojny światowej funkcje proboszczów w parafii św. Marcina w Opatowie spełniali kolejno trzej duchowni: ks. Andrzej Glibowski ${ }^{13}$ w latach

8 Parafia Biskupice została erygowana w 1957 r.

9 Przy kościele pw. Wniebowzięcia NMP erygowano parafię w 1990 r., wydzielając ją z parafii św. Marcina. Nowa parafia liczyła wtedy 2500 mieszkańców. Jubileuszowy Rocznik diecezji sandomierskiej 2000, Sandomierz 2001, s. 256-257.

10 Spis... 1939, dz. cyt., s. 102, 103.

11 Rocznik... 1958 r., dz. cyt., s. 67-68.

12 B. Stanaszek, Diecezja sandomierska..., dz. cyt., t. 1, s. 74-75.

13 Ks. Andrzej Glibowski (1881-1957) ur. 14 listopada 1881 r. w Iwaniskach. Syn Pio- 
1945-1957, ks. Stanisław Szczepaniak ${ }^{14}$ od 1957 do 1962 r. i ks. Tomasz Zadęcki ${ }^{15}$

tra i Józefy z d. Nowakowska. W latach 1892-1897 był uczniem Gimnazjum w Sandomierzu. W Seminarium Duchownym w Sandomierzu studiował od 1897 do 1903 r. Wyświęcony na kapłana 15 maja 1904 r. przez biskupa Stefana Zwierowicza. Był wikariuszem w parafii Sieciechów, a następnie parafii katedralnej w Sandomierzu oraz archiwistą Kurii Diecezjalnej. Po administrowaniu parafią Smogorzów i Włostów ponownie wikariusz, tym razem w parafii pw. św. Katarzyny w Radomiu. Obowiązki proboszcza spełniał w parafii Wyśmierzyce (1912-1917), Niekrasów (1917-1920), Mirzec (1920) i Waśniów (1920-1945). Krótko pełnił funkcję wicekanclerza i kanclerza Kurii Diecezjalnej w Sandomierzu (1917-1920). W 1919 r. został kanonikiem honorowym Kapituły Sandomierskiej, a w 1942 r. kanonikiem gremialnym Kapituły Opatowskiej. Od 1944 r. proboszcz konsultor diecezji sandomierskiej i Sędzia Prosynodalny. Będąc proboszczem w Opatowie był jednocześnie dziekanem tamtejszego dekanatu. Zmarł 16 stycznia 1957 r. i pięć dni potem został pochowany na miejscowym cmentarzu parafialnym. Archiwum Diecezji Sandomierskiej [dalej: ADS], Akta personalne [dalej: AP] ks. Andrzeja Glibowskiego, Karta z danymi osobowymi; B. Stanaszek, R. Nowakowski, Stownik biograficzny diecezji sandomierskiej XIX-XX w, t. 1, A-G, Sandomierz 2014, s. 229. Zob. „Kronika Diecezji Sandomierskiej” [dalej: KDS] 50 (1957), s. 59-62.

14 Ks. Stanisław Szczepaniak (1894-1962) ur. 3 września 1894 r. w Goryniu. Syn Marcina i Apolonii z d. Drela. Po ukończeniu Szkoły Powszechnej w Jedlińsku i Gimnazjum Męskiego w Chełmie studiował w Seminarium Duchownym w Sandomierzu (19131919). Wyświęcony na kapłana 29 maja 1919 r. przez biskupa Mariana Ryxa. Pracę duszpasterską wykonywał jako wikariusz parafii Białaczów (1919-1921), św. Mikołaja w Końskich (1920-1929), proboszcz parafii Miedzierza (1929-1946) i wicedziekan dekanatu radoszyckiego (1934-1946), proboszcz parafii Łoniów (1946-1957) i wicedziekan, a od 1954 r. dziekan dekanatu koprzywnickiego. W latach 1957-1962 był proboszczem w Opatowie i dziekanem dekanatu opatowskiego. W 1957 r. obdarzony został godnością kanonika gremialnego Kapituły Opatowskiej, a w 1961 r. mianowany proboszczem konsultorem diecezji sandomierskiej i Sędzią Prosynodalnym Sądu Biskupiego Kurii Diecezjalnej w Sandomierzu. Zmarł w Opatowie 7 listopada 1962 r. i trzy dni potem został pochowany na miejscowym cmentarzu parafialnym. ADS, AP ks. Stanisława Szczepaniaka, Karta z danymi osobowymi. Zob. KDS 56 (1963), s. $30-31$.

15 Ks. Tomasz Zadęcki (1895-1980) ur. 13 grudnia 1895 r. w Głowaczowie. Syn Wojciecha i Marianny z d. Gutowska. Był uczniem Szkoły Powszechnej w Głowaczowie, Gimnazjum Męskiego w Radomiu i alumnem Seminarium Duchownego w Sandomierzu. Święcenia kapłańskie przyjął z rąk biskupa Mariana Ryxa 21 lipca 1918 r. Był wikariuszem parafii Błotnica, Solec nad Wisłą i Żarnów. Następnie proboszczem w parafiach Kostrzyń, Bliżyn, Krzyżanowice, Wsola, Gielniów, Klimontów. Będąc wreszcie proboszczem w Pionkach (1950-1963) zajmował też stanowisko dziekana dekanatu pionkowskiego (1958-1963). Z kolei jako proboszcz parafii św. Marcina w Opatowie (1963-1970) był jednocześnie dziekanem dekanatu opatowskiego. Godność kanonika honorowego Kapituły Sandomierskiej uzyskał w 1961 r., a dwa lata później kanonika honorowego i gremialnego Kapituły Opatowskiej. W latach 1964-1974 sprawował urząd konsultora diecezji sandomierskiej, a w latach 1968-1974 Sędziego Prosynodal- 
w okresie od 1963 do $1970 \mathrm{r}$. Zapisali się oni zapewne w pamięci starszego pokolenia mieszkańców miasta. Wszyscy ci duchowni, zanim przybyli do Opatowa, zdobyli ogromne doświadczenie w pracy duszpasterskiej. Piastowali różnorakie funkcje w parafiach i instytucjach kościelnych diecezji sandomierskiej. Byli jednocześnie obdarzeni licznymi tytułami i godnościami w hierarchii Kościoła katolickiego. Proboszczowie ci wywodzili się z rodzin wiejskich, ale swe powołanie spełniali uprzednio także w ośrodkach miejskich i środowiskach przemysłowych. W dokumentach personalnych nie znaleziono informacji, aby władze świeckie blokowały ich nominacje na stanowiska proboszczów czy dziekanów w Opatowie. Takie uprawnienia w stosunku do proboszczów wykorzystywano w okresie stalinowskim, zwłaszcza rygorystycznie w latach 1953-1956, kiedy obowiązywał dekret o obsadzaniu duchownych stanowisk kościelnych z 9 lutego 1953 r. Wówczas księży począwszy od wikariusza, a skończywszy na arcybiskupie, których uznawano za przeciwników ustroju komunistycznego, próbowano usuwać z zajmowanych stanowisk, a na ich miejsce awansować duchownych skłonnych do współpracy z władzami PRL. Proboszczowie opatowscy swą działalnością i postawą nie dali podstaw, ani do żądań usunięcia z piastowanego stanowiska, ani przeniesienia na bardziej intratną placówkę duszpasterską.

Bardziej złożony jest obraz księży wikariuszy pracujących w Opatowie w latach 1945-1966. Dla niektórych była to pierwsza parafia, a dla innych kolejna w kapłańskiej drodze. Również zróżnicowany był ich czas pobytu w Opatowie. Łącznie w parafii św. Marcina pracowało kilkunastu księży wikariuszy. W kolejności chronologicznej byli to księża: Walenty Krakowiak ${ }^{16}$, Czesław Florkiewicz ${ }^{17}$, Ignacy Marian Ziembicki ${ }^{18}$, Stanisław Turzyński, Józef Dziadowicz ${ }^{19}$, Stefan Gawroński20,

nego Sądu Biskupiego w Sandomierzu. Od 1968 r. prałat Kapituły Opatowskiej. W wieku emerytalnym był rezydentem w parafii Ćmielów (1970-1977) i w Domu Księży Emerytów w Sandomierzu (1977-1980). W tym ostatnim zmarł 29 września 1980 r., a 1 października został pochowany na cmentarzu parafialnym w Klimontowie. ADS, AP ks. Tomasza Zadęckiego, Karta z danymi osobowymi. Zob. KDS 76 (1983), s. 190-192.

16 ADS, Akta kościoła kolegiaty i parafii w Opatowie (1866-1983) [dalej: AKO], Akt nominacji ks. Walentego Krakowiaka na wikariusza kooperatora w Opatowie, Sandomierz, 29 III 1945 r., s. 499; Spis... 1944-1945 r., s. 41; Spis... 1946 r., s. 48; B. Stanaszek, R. Nowakowski, Słownik biograficzny diecezji sandomierskiej XIX-XX w, t. 2, H-Ł, Sandomierz 2015, s. 148.

17 Ks. Czesław Florkiewicz (1915-1953). ADS, AP ks. Czesława Florkiewicza, Karta z danymi osobowymi. Zob. KDS 46 (1953), s. 90.

18 Ks. Ignacy Marian Ziembicki (1920-2011). ADS, AP ks. Ignacego Ziembickiego, Karta z danymi osobowymi; ADS, AKO (1866-1983), s. 501. Zob. KDS 104 (2011), s. 772-797.

19 Rocznik... 1948 r., s. 62; Rocznik... 1952/53 r., s. 56.

20 Rocznik... 1952/53 r., s. 56. 
Władysław Wyrwał²1, Wincenty Bień2 ${ }^{22}$, Czesław Tatar ${ }^{23}$, Józef Bi1 ${ }^{24}$, Marian Jaskólski $^{25}$, Stanisław Bartoszewski ${ }^{26}$, Bogumił Orłowski ${ }^{27}$, Marian Lucima ${ }^{28}$, Jan Gogacz ${ }^{29}$, Stanisław Groszek ${ }^{30}$, Krzysztof Knez ${ }^{31}$.

W Opatowie istniała Kapituła Kolegiacka, która nie miała takiego znaczenia jak Kapituła Katedralna w Sandomierzu. Jednak godności związane z Opatowem miały znaczenie prestiżowe i były wyróżnieniem dla zasłużonych duchownych. Szczegółową obsadę personalną Kapituły Kolegiackiej w Opatowie zamieścił we wspomnianej już pracy ks. Bogdan Stanaszek. Obejmuje ona wykaz godności w grupie kanoników gremialnych i honorowych w latach 1945-1965 32 .

W Opatowie po II wojnie nadal przebywały zakonnice ze Zgromadzenia SS. Franciszkanek Rodziny Maryi. Dysponujemy danymi, że w 1945 r. prowadziły one w mieście ochronkę i szwalnię (od 1917 r.). Z kolei w 1952 r. cztery siostry pracowały w opatowskim przedszkolu z dwoma oddziałami. W następnych latach (1956 i 1960 r.) przebywały tu trzy siostry z tego zgromadzenia, pracujące na plebanii. Dane z 1958 r. informują, że siostry opiekowały się nadal przedszkolem ${ }^{33}$. W Opa-

${ }^{21}$ Archiwum Państwowe w Kielcach [dalej: APK], Urząd Wojewódzki w Kielcach [dalej: UW] Wydział do Spraw Wyznań [dalej: WdSW], sygn. 214, k. 1.

${ }^{22}$ Rocznik... 1952 r., s. 56; APK, UW WdsW, sygn. 214, k. 1.

23 Władze świeckie Wojewódzki Zespół Organizacji Masowych [dalej: WZOM] w Kielcach w grudniu 1955 r. zgodziły się na przeniesienie ks. Czesława Tatara ze stanowiska wikariusza w Opatowie na stanowisko administratora w Biskupicach. B. Stanaszek, Diecezja sandomierska..., dz. cyt., t. 1, aneks 5; APK, UW WdsW, sygn. 214, k. 1.

${ }^{24}$ WZOM w Kielcach najpierw nie zaakceptował kandydatury wikariusza ze Skaryszewa na stanowisko wikariusza do Opatowa, a następnie po kilkunastu dniach, w lipcu 1955 r., odpowiedział pozytywnie na wniosek biskupa Jana Lorka. B. Stanaszek, Diecezja sandomierska..., dz. cyt., t. 1 , aneks 5.

25 WZOM w Kielcach wyraził zgodę w lutym 1956 r. na objęcie przez absolwenta Katolickiego Uniwersytetu Lubelskiego ks. Jana Jaskólskiego stanowiska wikariusza w Opatowie. Po upływie kilku miesięcy odmówiono staraniom biskupa sandomierskiego, który chciał przenieść ks. Jaskólskiego z Opatowa na wikariat do parafii NSJ w Radomiu. B. Stanaszek, Diecezja sandomierska..., dz. cyt., t. 1, aneks 5; APK, UW WdSW, sygn. 214, k. 1.

${ }^{26}$ Ks. Stanisław Bartoszewski (1921-1994). Wikariat w Opatowie objął na podstawie zgody kieleckiego WZOW w lipcu 1956 r.. ADS, Karta z danymi osobowymi ks. Stanisława Bartoszewskiego. B. Stanaszek, Diecezja sandomierska..., dz. cyt., t. 1, aneks 5; APK, UW WdSW, sygn. 214, k. 1. Zob. KDS 1994, nr 87, s. 278-283.

27 Rocznik... 1958 r., dz. cyt., s. 67.

28 APK, UW WdsW, sygn. 214, k. 1.

29 APK, UW WdsW, sygn. 214, k. 1.

30 ADS, Akta Wizytacji Pasterskiej 1962-1969, Protokół wizytacji pasterskiej odbytej w parafii Opatów przez J.E. Ks. Biskupa D-ra Piotra Gołębiowskiego 20 VI 1964 r.; APK, UW WdSW, sygn. 214, k. 1.

31 ADS, Akta Wizytacji Pasterskiej 1962-1969, Protokół wizytacji, 20 VI 1964 r.

32 B. Stanaszek, Diecezja sandomierska..., dz. cyt., t. 1, s. 53, aneks 2.

33 B. Stanaszek, Diecezja sandomierska..., dz. cyt., t. 1, aneks 6. Lakoniczne informacje 
towie posługiwały też siostry ze Zgromadzenia SS. Miłosierdzia św. Wincentego à Paulo, które pracowały w Szpitalu św. Leona. Pełniły tam m.in. funkcje pielęgniarek oddziałowych. Z danych do 1960 r. wynika, że znajdowało tam zatrudnienie sześć sióstr szarytek. Potem liczbę tę stopniowo redukowano. W 1963 r. przełożona zgromadzenia s. Eugenia Gontarek w Szpitalu Powiatowym w Opatowie przepracowała ponad 25 lat. Szarytki mieszkały w bardzo skromnych warunkach, trzyizbowym budynku obok szpitala, który był własnością służby zdrowia ${ }^{34}$.

W Opatowie mieli swą placówkę ojcowie bernardyni. O nich informują m.in. teczki sporządzone przez pracowników państwowej administracji do spraw wyznaniowych - „wyznaniowców”, o których będzie mowa niżej. Sporządzona na początku lutego 1950 r. kartoteka podaje, że w klasztorze OO. Bernardynów w Opatowie przebywało pięciu zakonników (Franciszek Kaczor, Marceli Sykuła, Teodor Rączka, Ludwik Kopiel i Władysław Świadek) $)^{35}$. Zarządzali oni zabytkowym kościołem, nie stanowiącym parafii, który mógł pomieścić około tysiąc osób. Zakonnicy mieszkali w zabytkowym klasztorze, wymagającym remontu. $\mathrm{Na}$ mieszkańców wywierali - jak pisano - „przemożny wpływ”. Zasadniczo utrzymywali się z prowadzenia rekolekcji i misji w różnych parafiach oraz nauczania religii w szkołach. W tym czasie posiadali nieruchomość gruntową o powierzchni 3,93 ha, ogród owocowy o powierzchni 0,56 ha, niewykorzystane trzy stawy rybne, stodołę i stajnię ${ }^{36}$.

W czasach trudnych pod względem politycznym i duszpasterskim władzom kościelnym bardzo zależało na dyscyplinie podległego im kleru. Władze diecezjalne w Sandomierzu zabiegały więc o należytą frekwencję księży na konferencjach dekanalnych. Niektórych w tej kwestii upominano. Tak było podczas konferencji w Opatowie 28 lutego 1949 r., kiedy zebrani księża sformułowali „swoje głębokie niezadowolenie" wobec uchylania się konfratrów od udziału w kongregacji dekanalnej ${ }^{37}$. W opatowskiej parafii wizytacje kanoniczne przeprowadził biskup sandomierski Jan Kanty Lorek 4 czerwca 1949 r. ${ }^{38}, 7$ i 8 czerwca 1958 r..$^{39}$ oraz 20 czerwca

o działalności sióstr posiadał m.in. WdSW w Kielcach. W kartotece odnotowywano ich dane personalne i charakterystyki. W jednej z notatek napisano: „Do Polski Ludowej ustosunkowane są biernie". APK, UW WdSW, sygn. 416, k. 2.

34 ADS, Akta Wizytacji Pasterskiej 1962-1969, Uwierzytelniony odpis protokołu wizytacji pasterskiej przeprowadzonej 7 VI 1958 r. w parafii Opatów, Opatów, 8 VI 1958 r.; APK, UW WdSW, sygn. 415, s. 1 i nn; B. Stanaszek, Diecezja sandomierska..., dz. cyt., t. 1 , aneks 6.

35 APK, UW WdSW, sygn. 413, k. 1.

36 APK, UW WdSW, sygn. 413, k. 1.

37 Cyt. za: B. Stanaszek, Diecezja sandomierska..., dz. cyt., t. 1, s. 70.

38 Rocznik... 1958 r., s. 67; ADS, Akta Wizytacji Pasterskiej 1942-1951, Protokół wizytacji kanonicznej parafii św. Marcina w Opatowie, Opatów, 4 VI 1949 r.

39 ADS, Akta Wizytacji Pasterskiej 1962-1969, Uwierzytelniony odpis protokołu wizytacji pasterskiej przeprowadzonej 7 VI 1958 r. w parafii Opatów, Opatów, 8 VI 1958 r. 
1964 r. - biskup sufragan Piotr Gołębiowski ${ }^{40}$. Z kolei misje parafialne zorganizowano w $1960 \mathrm{r}^{41}$.

Jeśli chodzi o warunki funkcjonowania parafii, to trzeba stwierdzić, że kościół św. Marcina z XII w. został częściowo uszkodzony podczas działań wojennych w $1944 \mathrm{r}^{42}$ Ważne było usunięcie zniszczeń i podjęcie budowy zburzonej plebanii. W Kurii Diecezjalnej w Sandomierzu planowano, że dotychczasowy wikariusz ks. Walenty Krakowiak, mający odpowiedni autorytet wśród parafian i pewne możliwości działania wobec nowych władz państwowych, będzie najlepszym wykonawcą tych zadań ${ }^{43}$. Potwierdza te oczekiwania decyzja Wydziału Kultury i Sztuki Urzędu Wojewódzkiego w Kielcach z 18 czerwca 1945 r. o przekazaniu symbolicznej kwoty 20 tys. zł ,zasiłku na roboty konserwatorskie /zabezpieczenie/ tamtejszej zabytkowej kolegiaty" ${ }^{4}$. Z lektury kościelnych roczników wynika, że kolegiatę odrestaurowano w 1946 r., zaś w latach 50. poddano remontowi ${ }^{45}$. W protokole wizytacji kanonicznej z 4 czerwca 1949 r. zapisano: „Stan kościoła z powodu działań wojennych bardzo uszkodzony; wymaga dużego i kosztownego remontu" ${ }^{46}$, dlatego należy sądzić, że zaraz po wojnie naprawiono tylko uszkodzony od pocisków dach. Budynek plebanii został zburzony, a wikariat był „w stanie mniej niż średnim”. Z kolei zabudowania gospodarcze określono jako „w bardzo lichym stanie”. Nie można było liczyć na szybką poprawę sytuacji skoro ofiarność parafian była „mała”, pomimo przychylnego odnoszenia się wiernych do materialnych inicjatyw proboszcza ${ }^{47}$. Był to efekt słabej kondycji finansowej ówczesnego społeczeństwa. W 1958 r. wizytujący parafię biskup Lorek z uznaniem odniósł się do kontynuacji prac remontowych, przejętych ,z pietyzmem" po zmarłym ks. Glibowskim przez ks. Szczepaniaka. Od roku trwał remont południowej wieży, do której zakupiono zegar. Zbudowano nowe betonowe schody,

40 ADS, Akta Wizytacji Pasterskiej 1962-1969, Protokół wizytacji pasterskiej odbytej w parafii Opatów przez J.E. Ks. Biskupa D-ra Piotra Gołębiowskiego 20 VI 1964 r.

${ }^{41}$ Rocznik diecezji sandomierskiej 1972, Sandomierz 1972, s. 73.

42 Spis... 1946 r., s. 49.

43 ADS, AKO, k. 500.

44 ADS, AKO, k. 502.

45 Rocznik... 1948 r., s. 62. Poprzednia renowacja świątyni odbyła się w 1632 r. Spis... 19441945 r., s. 41. O remoncie kolegiaty informują kolejne roczniki diecezji sandomierskiej oraz korespondencja biskupa z władzami państwowymi. APK, UW WdSW, sygn. 214, k. 2-4, 8-11; Rocznik... 1952/53 r., s. 56; Rocznik... 1958 r., s. 67.

46 ADS, AKDS, Akta Wizytacji Pasterskiej 1942-1951, Protokół wizytacji kanonicznej parafii św. Marcina w Opatowie, Opatów, 4 VI 1949 r. W odpisie dodatku do tego protokołu mówiono o dachu podziurawionym pociskami.

47 Tamże. Urzędnicy wyznaniowi w kartotece parafii Opatów na początku lat 50. stan obiektów kościelnych ujęli następująco: „dom drewniany parterowy w stanie lichym, wikariat murowany w stanie dobrym i schronisko dla starców przy cmentarzu w użytkowaniu ks. Glibowskiego". Podano też wielkość mienia rolniczego: powierzchnia rolnicza 3,74 ha, ogród owocowy o powierzchni 0,4 ha, ,stodoła zbudowana z materiału zużytkowanego”. APK, UW WdSW, sygn. 214, k. 1. 
prowadzące z cmentarza przykościelnego na ulicę Kościuszki i odnowiono bramę wejściową. Przeprowadzono remont wikariatu i mieszkania kościelnego. Zgromadzono cement i wapno przeznaczone do dalszych prac. Zakupiono też silnik do organów. Szereg ważnych działań oczekiwało realizacji, a wśród nich potrzeba budowy plebanii ${ }^{48}$. Kolejny proboszcz w Opatowie przeprowadził m.in. naprawę rynien na dachu kolegiaty od strony północnej, częściowe pomalowanie dachu nad boczną nawą, renowację trzech stron ogrodzenia, naprawę dachu na dzwonnicy z nadaniem mu pierwotnego wyglądu, instalację nagłośnienia wewnątrz świątyni ${ }^{49}$. Natomiast restauracji kościoła OO. Bernardynów z połowy XVIII w. dokonano w 1957 r. i kolejnych latach ${ }^{50}$.

\section{Władze świeckie zajmujące się polityką wyznaniową}

Polityka państwa wobec Kościoła na poziomie powiatowego miasta Opatowa wynikała z koncepcji, instrukcji i poleceń służbowych płynących od partyjno-państwowego aparatu centralnego, przekazywanych za pośrednictwem wojewódzkich władz partyjnych w Kielcach (Komitet Wojewódzki Polskiej Partii Robotniczej do grudnia 1948 r. i następnie Komitet Wojewódzki Polskiej Zjednoczonej Partii Robotniczej). Aparat partyjno-państwowy do spraw wyznań był zorganizowany w trzech uzupełniających się wzajemnie pionach: partyjnym, administracyjnym i policyjnym. Bieżące działania w stosunku do Kościoła konstruowano w Komitecie Powiatowym Polskiej Partii Robotniczej (KP PPR), a od końca 1948 r. Polskiej Zjednoczonej Partii Robotniczej (KP PZPR). Partia komunistyczna koordynowała pracę podległych sobie struktur lokalnej administracji i aparatu bezpieczeństwa korzystając z tzw. „trójek powiatowych" czy później zespołów powiatowych. W dużym uproszczeniu można powiedzieć, że w latach 1950-1957 należeli do nich I sekretarz KP PZPR, szef Powiatowego Urzędu Bezpieczeństwa Publicznego (PUBP) i kierownik Referatu do Sprawa Wyznań (RdSW) przy Prezydium Powiatowej Rady Narodowej (PPRN). Dowodów istnienia tego układu można podać bezliku. Przykładem może być udokumentowana działalność Referatu Organizacji Masowych przy KW PZPR w Kielcach, który zajmował się organizacją walki z Kościołem katolickim na obszarze województwa kieleckiego. W kolejnych latach, zgodnie z poleceniem Egzekutywy KW PZPR w Kielcach doszło do znacznego zwiększenia składu osobowego powiatowych i miejskich zespołów do spraw kleru. Powiatowy zespół do spraw kleru w Opatowie w 1965 r. liczył aż 10 osób: I sekretarz KP PZPR, sekretarz propagandy, zastępca komendanta MO (czyli szef miejscowej Służby Bezpieczeństwa - SB), kierownik

48 ADS, Akta Wizytacji Pasterskiej 1962-1969, Uwierzytelniony odpis protokołu wizytacji pasterskiej przeprowadzonej 7 VI 1958 r. w parafii Opatów, Opatów, 8 VI 1958 r.

49 ADS, Akta Wizytacji Pasterskiej 1962-1969, Protokół wizytacji pasterskiej odbytej w parafii Opatów przez J.E. Ks. Biskupa D-ra Piotra Gołębiowskiego 20 VI 1964 r.

50 Rocznik... 1958 r., s. 67. Poprzednia restauracja kościoła OO. Bernardynów została przeprowadzona w 1902 r.. Spis... 1946 r., s. 49. Zob. APK, UW WdSW, sygn. 413, k. 4-12. 
Wydziału Spraw Wewnętrznych PPRN, kierownik Ośrodka Propagandy, przewodniczący PPRN, podinspektor, przewodniczący Zarządu Powiatowego Związku Młodzieży Socjalistycznej, prezes Towarzystwa Szkoły Świeckiej, prezes Stowarzyszenia Ateistów i Wolnomyślicieli. Przykładowo jesienią 1965 r. zespół ten opracował ogólny plan obchodów 1000-lecia państwa polskiego ${ }^{51}$. Mamy więc odpowiedź jaki był w latach 60. XX w. główny cel stymulowanych przez Warszawę przedsięwzięć logistycznych. Mówiąc w skrócie szło o pogłębienie laicyzacji, a właściwie ateizacji społeczeństwa i rywalizacji z kościelnym programem Wielkiej Nowenny Tysiąclecia jako duchowym przygotowaniem do obchodów Milenium Chrztu Polski.

W Opatowie miały swą siedzibę KP PPR/PZPR, Starostwo Powiatowe, zastąpione w 1950 r. przez Prezydium Powiatowej Rady Narodowej. Z kolei Powiatowy Urząd Bezpieczeństwa Publicznego w Opatowie miał swą siedzibę w Ostrowcu Świętokrzyskim (PUBP Opatów w Ostrowcu Świętokrzyskim). Charakterystykę większości jej funkcjonariuszy zajmujących się walką z Kościołem przeanalizowała Roksana Szczypta-Szczęch ${ }^{52}$. Struktura Opatowskiego UB została przekształcona w końcu 1956 r. i podporządkowana Komendzie Powiatowej Milicji Obywatelskiej. Zastępca tegoż komendanta odpowiadał za powiatową SB. Jak wspomniano, w latach 1945-1950 Opatów był siedzibą Starostwa Powiatowego. Sprawami lokalnej polityki wobec Kościoła katolickiego zajmował się jego Referat Społeczno-Polityczny. Przykładowo w 1946 r. podlegały mu oprócz parafii w Opatowie także 43 inne jednostki podstawowe $\mathrm{w}$ administracji kościelnej z dekanatu opatowskiego, kunowskiego, słupskiego, staszowskiego i zawichojskiego ${ }^{53}$. Z kolei w latach 1950 1957 działał w Opatowie przy PPRN Referat do Spraw Wyznan ${ }^{54}$. Wytworzoną tam dokumentację - podobnie jak wszystkich powiatowych referatów w kraju - polecono spalić na początku 1957 r. Raportował o tym do Warszawy dyrektor Wydziału do Spraw Wyznań (WdSW) w Kielcach Stefan Jarosz. Ostała się jedynie część dokumentów, które trafiły w związku załatwianiem konkretnych spraw do kieleckiego WdSW lub Urzędu do Spraw Wyznań w Warszawie (UdSW). Na podstawie szczątkowo zachowanych materiałów archiwalnych wytworzonych w Opatowie wiemy, że funkcję kierownika opatowskiego RdSW pełnił m.in. Władysław Giezek ${ }^{55}$.

51 B. Stanaszek, Diecezja sandomierska... dz. cyt., t. 1, 105.

52 R. Szczypta-Szczęch, Powiatowy Urząd Bezpieczeństwa Publicznego..., dz. cyt., s. 50-51, 55-77.

53 Łącznie teren ten obejmował prawie 160 tys. wiernych. R. Gryz, Państwo a Kościót w Polsce 1945-1956 na przykładzie województwa kieleckiego, Kraków 1999, s. 63.

${ }^{54}$ RdSW w Opatowie przestał działać 1 lutego 1957 r.. W województwie kieleckim zlikwidowano wtedy 21 referatów, a miesiąc potem dalsze cztery. Archiwum Akt Nowych w Warszawie [dalej: AAN], Urząd do Spraw Wyznań [dalej: UdSW], sygn. 31/182, k. 16.

55 R. Gryz, Państwo a Kościół..., dz. cyt., s. 50. W Archiwum Państwowym w Kielcach w zespole Urząd Wojewódzki w Kielcach Wydział do Spraw Wyznań zachowała się jednostka archiwalna zawierająca 137 kart pt. Akta parafii rzym.-kat. pw. Św. Marcina w Opatowie 1957-1987. W kieleckiej kartotece „wyznaniówki” opatowska parafia miała nr 256/Kiel. 
Praca opatowskich kierowników RdSW nie była dobrze oceniana. Zresztą podobnie jak większości referentów powiatowych do spraw wyznann ${ }^{56}$. Dlatego w wojewódzkim RdSW w Kielcach organizowano comiesięczne odprawy. W tym kontekście przełożony skrytykował postawę m.in. kierownika RdSW w Opatowie, wytykając mu zaniedbania jeśli idzie o frekwencję na tychże naradach roboczych ${ }^{57}$. Oceny pracowników wpłynęły na decyzję z połowy 1951 r. o zmianie obsady personalnej referatów w Opatowie i Starachowicach ${ }^{58}$. W kolejnych latach sytuacja nie uległa poprawie. Kierownik Wydziału Organizacji Masowych KW PZPR w Kielcach Władysław Skorek przeprowadził w końcu 1954 r. akcję sporządzenia charakterystyk kierowników Powiatowych i Miejskich RdSW. Wymiana kierownika RdSW m.in. w Opatowie rok wcześniej nic nie zmieniła. Wobec kolejnego referenta, chodzi o Bernarda Nowakowskiego, napisano, że był „,pracowity”, lecz wyniki osiągał słabe. Mogło to być skutkiem notorycznego wykorzystywania tych pracowników do innych, pozawyznaniowych zadań oraz słabym nadzorem ze strony KP PZPR ${ }^{59}$.

Podobne kłopoty były też z pracownikami, którzy sprawami kościelnymi zajmowali się sporadycznie, gdyż ich kompetencje były zasadniczo inne. Jarosz miał problem np. z architektem powiatowym w Opatowie, który w 1959 r. wydał zezwolenie na budowę kaplic pod pretekstem domów mieszkalnych ${ }^{60}$. Nie dotyczyło to oczywiście Opatowa, gdzie nie było potrzeby wznoszenia nowego obiektu sakralnego. Wykorzystując metodę ekstrapolacji można stwierdzić, że mechanizm działania aparatu partyjno-państwowego był we wszystkich miastach powiatowych zbliżony do siebie. Ludzie aparatu partyjnego sterowali przedsięwzięciami, funkcjonariusze władz bezpieczeństwa prowadzili inwigilację i akcje specjalne, a urzędnicy państwowej administracji do spraw wyznań wdrażali otrzymywane polecenia. Zajmujący się zwalczaniem wpływów Kościoła Referat V PUBP w Opatowie (z siedzibą w Ostrowcu Świętokrzyskim) stosował takie same metody pracy operacyjnej jak inne jego odpowiedniki. Początkowo najistotniejsza była inwigilacja środowiska kościelnego, zarówno duchownych jak i tzw. aktywu klerykalnego spośród świeckich. W dekanatach kunowskim i opatowskim oraz częściowo słupskim i staszowskim obejmujących ponad 40 parafii i ponad 120 duchownych, próbowano tworzyć sieć informatorów o różnym statusie ${ }^{61}$. Dzięki osobowym źródłom informacji można było prowadzić różnego rodzaju gry operacyjne z wykorzystaniem metod prowokacji, szantażu, zastraszania i korumpowania. Opatowski (ostrowiecki) PUBP, podobnie jak w innych powiatach, uaktywnił swe antykościelne działania w 1949 r.. Rozpoznaniu postaw duchowieństwa w stosunku do nowej rzeczywistości poli-

\footnotetext{
APK, UW WdSW, sygn. 214, k. 1.

56 R. Gryz, Państwo a Kościół..., dz. cyt., s. 44-49.

57 B. Stanaszek, Diecezja sandomierska..., dz. cyt., t. 1, s. 134.

58 AAN, UdSW, sygn. 7/5, Sprawozdanie RdSW PWRN w Kielcach za II kwartał 1951 r.

59 B. Stanaszek, Diecezja sandomierska..., dz. cyt., t. 1, s. 138-139.

60 B. Stanaszek, Diecezja sandomierska..., dz. cyt., t. 1, s. 145.

61 R. Szczypta-Szczęch, Powiatowy Urzad Bezpieczeństwa Publicznego..., dz. cyt., s. 54-55.
} 
tycznej, służyły organizowane przy różnych okazjach rozmowy, na które wzywano księży do RdSW lub PUBP. W ten sposób poszukiwano też nowych informatorów. „Perfidię ubeckich planów - jak napisał Bogdan Stanaszek - ukazują materiały wytworzone w tym czasie przez PUBP w Opatowie". Wstępne rozmowy z księżmi z dekanatu opatowskiego, wg specjalnego planu, miały umożliwić poddanie wybranych duchownych dalszej presji. Efekty były jednak dość mocno ograniczone. Funkcjonariusze PUBP planowali dyskretnie skontaktować się z ks. Stanisławem Skurskim, proboszczem małej parafii Wszechświęte w pobliżu Opatowa i przy jego udziale „dokonać podziału i zidentyfikować księży, którzy stanowią element wrogi, bierny, pozytywny itd." ${ }^{\prime 2}$. Narzędziem dla takiej segregacji było tworzenie teczek osobowych, w których zamieszczano m.in. charakterystyki wszystkich duchownych ${ }^{63}$. W następnych latach zasadą stało się posiadanie przynajmniej jednego tajnego współpracownika w każdym dekanacie ${ }^{64}$.

Do Okręgowej Komisji Księży przy ZBoWiD w Kielcach, czyli prorządowej formacji księży „patriotów”, należało początkowo pięciu księży. Wśród nich nie było żadnego kapłana z Opatowa ${ }^{65}$. Spośród opatowskich księży nie planowano też nikogo pozyskiwać do współpracy. Na temat duchownych z powiatu opatowskiego przychylnie odnoszących się do władz PRL informował UB współpracownik tych służb o pseudonimie „Zefir”. Kłopoty odnotowano też na polu organizacji zjazdów dla prorządowych księży. Na zjazd poprzedzający uchwalenie konstytucji PRL, który zorganizowano 15 lipca 1952 r. do Sandomierza przybyło czterech księży, a do Opatowa pięciu. W pozostałych powiatach duchowni zbojkotowali akcję ${ }^{66}$. W następnych latach sytuacja nie uległa poprawie. Świadczy o tym jeden z kolejnych zjazdów, tym razem w ramach struktury pod nazwą Komisja Duchownych i Świeckich Działaczy Katolickich, który zaplanowano w Opatowie 1 czerwca 1955 r. Z prawie siedemdziesięciu zaproszonych księży przybyło na zebranie zaledwie ośmiu, z czego ani jeden z Opatowa czy Ostrowca Świętokrzyskiego. Nie pomogło zaoferowanie środków lokomocji i dodatkowych ,atrakcji”, takich jak wycieczka do spółdzielni produkcyjnej w Przeuszynie i Gierczycach. Aktywista ks. Stanisław

${ }^{62}$ Cytaty za: B. Stanaszek, Diecezja sandomierska..., dz. cyt., t. 1, s. 154-155. Ks. Stanisław Skurski był m.in. członkiem Stronnictwa Ludowego. Uczestniczył w Kongresie Jedności Ruchu Ludowego w listopadzie 1949 r., na którym zlikwidowano resztki opozycyjnego PSL i powołano Zjednoczone Stronnictwo Ludowe. R. Gryz, Państwo a Kościół..., dz. cyt., s. 197.

63 Zob. APK, UW WdsW, sygn. 414, k. 4.

64 R. Szczypta-Szczęch, Powiatowy Urząd Bezpieczeństwa Publicznego..., dz. cyt., s. 112-118.

${ }^{65} \mathrm{Na}$ terenie powiatu opatowskiego posługiwali wtedy (1952 r.) następujący księża członkowie OKK (księża ,patrioci”): Eugeniusz Buczkowski z Rakowa, Walenty Krakowiak z Gierczyc, Wacław Pośpieszyński z Ostrowca Świętokrzyskiego, Stanisław Skrok z Ćmielowa i Marian Wójcik z Malic. B. Stanaszek, Diecezja sandomierska..., dz. cyt., t. 1, s. 213.

66 B. Stanaszek, Diecezja sandomierska..., dz. cyt., t. 1, s. 213-214. 
Skurski obciążał za ten stan biskupa Jana Lorka, który - jak twierdził duchowny „terroryzuje księży”67.

Księży „postępowych” władze PRL starały się wykorzystać w różnych akcjach. Tak było z kampanią wyborczą do rad narodowych w końcu 1954 r. Kandydatem do Powiatowej Rady Narodowej w Opatowie został ks. Józef Jędrasik proboszcz z Lasocina ${ }^{68}$ (dekanat zawichojski). To był jednak epizod, natomiast ks. Skurskiego wykorzystywano notorycznie. W swej notatce z 16 marca 1962 r. inspektor WdSW z Kielc Mieczysław Woś charakteryzował księdza pracującego w parafii Szydłowiec, gdzie proboszczem był ks. Skurski. Miał on odnosić sukcesy w temperowaniu wikariusza, który wcześniej pracował koło Opatowa w Iwaniskach. Tam sprzeciwiał się działaniom władz podczas tzw. akcji dekrucyfikacyjnej w 1959 r. Polegała ona na usuwaniu krzyży ze ścian w obiektach publicznych, zwłaszcza w szkołach. W rozmowie z przewodniczącym Prezydium Rady Narodowej w Opatowie ksiądz powiedział: „wystąpiliście do walki z krzyżami i wiarą, postępujecie jak Hitler i was spotka [to] co jego spotkało" ${ }^{6}$. Z powodu aktywności duszpasterskiej ks. Antoni Gnoiński - późniejszy proboszcz i dziekan w Opatowie - miał też m.in. problemy z nadmiernym opodatkowaniem w Szydłowcu, a następnie w Staszowie ${ }^{70}$. Generalnie jednak można stwierdzić, że powiat opatowski o ile chodzi o lata stalinowskie był słabo nasycony księżmi „patriotami” i silnie „wrogimi” duchownymi. Natomiast wziąwszy pod uwagę początek lat 60 . XX w., kiedy odbudowywano prorządowe struktury w oparciu o tzw. księży caritasowców (nazwa od Kół Księży Caritas), w powiecie opatowskim, kielecki Wydział do Spraw Wyznań zaliczał do księży „umiarkowanych” 30 duchownych, do księży „,wrogich” - 29, zaś do „pozytywnych” ledwie trzech ${ }^{71}$. Wniosek nasuwa się jeden: pomimo użycia ogromnych środków finansowych i organizacyjnych nie zdołano zdezintegrować środowiska duchownych. Na imiennej liście księży z diecezji sandomierskiej należących do Komisji Księży „Caritas” w Kielcach z 1965 r., obejmującej 100 księży, w tym z diecezji sandomierskiej 36, znalazł się o. Filip Lewandowski, bernardyn z Opatowa ${ }^{72}$.

Interesujące są informacje o księżach klasyfikowanych przez władze PRL na przeciwnym biegunie. W 1954 r. spośród 22 dziekanów w diecezji sandomierskiej czterech zaliczono do grona, które cechować miał „wrogi stosunek do Polski Ludowej”. Byli to Władysław Muszalski z Suchedniowa, Leonard Chojnacki z Potworowa, Andrzej Glibowski z Opatowa i Tomasz Zadęcki ze Zwolenia. O proboszczu i dziekanie z Opatowa ks. Andrzeju Glibowskim napisano w jego charakterystyce,

${ }^{67}$ B. Stanaszek, Diecezja sandomierska..., dz. cyt., t. 1, s. 236-237.

68 B. Stanaszek, Diecezja sandomierska..., dz. cyt., t. 1, s. 232.

69 APK, UW WdSW, sygn. 539, k. 21.

70 APK, UW WdSW, sygn. 539, Korespondencja WdSW w Kielcach z UdSW w Warszawie, k. 22-26, 28-38.

71 B. Stanaszek, Diecezja sandomierska..., dz. cyt., t. 1, s. 256, 268.

${ }^{72}$ B. Stanaszek, Diecezja sandomierska..., dz. cyt., t. 1, s. 279. Zob.: APK, UW WdSW, sygn. 414, k. 21. 
że jest „(...) wrogo ustosunkowany do Polski Ludowej. Wobec przedstawicieli władz państwowych zajmuje dwulicową postawę starając siebie przedstawić w świetle dodatnim. Jest gorliwym wykonawcą zarządzeń bpa Lorka. Wobec księży surowy i wymagający, wpaja posłuszeństwo i oddanie dla hierarchii kościelnej”. W podobny sposób scharakteryzowano późniejszego proboszcza w Opatowie ks. Zadęckiego: „aktywnie organizuje prace duszpasterskie, usilnie zabiega o erygowanie nowych parafii i budowę kościołów. Prowadzi szeroką mobilizację wiernych i inspiruje do interwencji u władz państwowych o zezwolenia. Posłuszny i oddany b[isku]powi Lorkowi, wrogo ustosunkowany do księży postępowych, których działalność stara się ograniczać i zwalczać"ᄁ3.

Dla stanu kapłańskiego i parafian tacy księża byli wzorem. Z kolei władzom świeckim zupełnie nie odpowiadali. W przypadku ks. Glibowskiego zastanawiające jest dlaczego te nie domagały się jego usunięcia z funkcji w Opatowie. Być może wynikało to z podeszłego wieku kapłana. W odniesieniu do ks. Tomasza Zadęckiego kilka lat później, w 1962 r. jego kandydatura na proboszcza i dziekana w Opatowie została na krótko zablokowana na skutek kontaktów ze Służbą Bezpieczeństwa tajnego współpracownika o pseudonimie „Wąkop” "74.

Władze PRL subiektywnie oceniały działalność opatowskich bernardynów. W jednej z opinii kierownika WdSW w Kielcach Stefana Jarosza z 8 grudnia 1959 r. czytamy: „Członkowie zgromadzenia przebywający w Opatowie do Polski Ludowej ustosunkowani są negatywnie - lecz wrogiej działalności nie prowadzą. Są natomiast bardzo aktywni na odcinku pobudzania fanatyzmu religijnego na terenie Opatowa i sąsiednich wiosek. W ubiegłym roku byli organizatorami wielkiej uroczystości kościelnej związanej z obchodami Millenium, a także byli cichymi inspiratorami cudownego odnowienia obrazu. Na pomoc Państwa [w remoncie klasztoru - R.G.] Zgromadzenie absolutnie nie zasługuje" 75 . Tak też się stało. Władze Funduszu Kościelnego w Warszawie nie przyznały subwencji dla wnioskodawcy i przełożonego zgromadzenia o. Jakundyna Andrzeja Łaby ${ }^{76}$.

\section{Najważniejsze konflikty w relacjach państwo-Kościól}

W pierwszych miesiącach po wojnie najważniejszą sprawą dla środowiska komunistycznej lewicy było utrwalenie, zdobycie władzy, utrwalenie systemu politycznego i unicestwienie oddziałów zbrojnego podziemia niepodległościowego, które swój rodowód wywodziło głównie ze środowisk Armii Krajowej (AK). Sporadycznie z takimi formacjami związani byli księża katoliccy. W okolicach Sienna

73 Cyt. za: B. Stanaszek, Diecezja sandomierska..., dz. cyt., t. 1, s. 320. Zob. R. SzczyptaSzczęch, Powiatowy Urząd Bezpieczeństwa Publicznego..., dz. cyt., s. 90-93, 97, 109, 122, 124, 125.

74 B. Stanaszek, Diecezja sandomierska..., dz. cyt., t. 1, s. 367.

75 APK, UW WdSW, sygn. 413, k. 10.

76 APK, UW WdSW, sygn. 413, k. 12. 
i Opatowa działała m.in. grupa kierowana przez ks. Stanisława Domańskiego, który podczas wojny był kapelanem AK. Nie zdołał on uchronić swych współtowarzyszy przed represjami i wyprowadzić ich z Polski. Jego śmierć 10 marca 1946 r. z rąk funkcjonariuszy UB w Starachowicach, z pewnością odbiła się głośnym echem wśród duchownych i katolików w Opatowie. Został on pochowany na cmentarzu w rodzinnych Strzyżowicach ${ }^{77}$. Być może podobnie było z okrutną zbrodnią, której dokonano w parę dni potem - 14 marca - na księdzu Janie Trojnarze z parafii Pętkowice w dekanacie soleckim ${ }^{78}$.

Istotnym polem konfliktu między władzami państwowymi a kościelnymi było wprowadzenie świeckiego charakteru instytucji małżeństwa i powołanie Urzędów Stanu Cywilnego (USC). Po zerwaniu konkordatu (12 września 1945 r.) uchwalono dekret o nowym prawie małżeńskim (25 września 1945 r.), który wszedł w życie 1 stycznia 1946 r. W gminach powołano USC, które miały rejestrować urodzenia, małżeństwa i zgony. Odebrano moc prawną kościelnym zapisom w księgach metrykalnych. Sprawa odpisów tych ksiąg bądź przejęcia ich duplikatów trwała do 1948 r. Cała akcja spotkała się z oporem społeczeństwa i z trudem organa władzy na Kielecczyźnie wprowadzały w życie nowe regulacje. Podczas kwerendy archiwalnej nie spotkano tego typu informacji z terenu Opatowa ${ }^{79}$. Jednak o trudnościach w tworzeniu gminnych USC mówiono na zebraniu partyjnym jeszcze w $1958 \mathrm{r}$. Na posiedzeniu plenarnym PZPR w Opatowie jedna z dyskutantek powiedziała: „Warto by również zastanowić się nad urządzeniem [tak w tekście protokołu - R.G.] lokali GRN do pobierania ślubów cywilnych, gdyż są one w opłakanym stanie, co w dużej mierze odrzuca młodzież"»o.

W okresie budowy nowego ustroju, komuniści ogromne znaczenie przykładali do akcji wyborów do parlamentu. Siłowe i propagandowe rozprawienie się z przeciwnikami politycznymi (zbrojnymi organizacjami niepodległościowymi i partiami opozycji politycznej) przed wyborami było rozwiązaniem priorytetowym. Stąd maksymalne odsunięcie wyborów w czasie, któremu służył pomysł poprzedzenia tego

77 G. Sado, O Polskę biało-czerwona. Ksiądz Stanisław Domański ps. „, Cezary” (1914-1946), Kielce 2009; R. Gryz, Państwo a Kościół..., dz. cyt., s. 159-161.

78 Ksiądz Jan Trojnar, film z serii „Z archiwum IPN”, TVP 2009. W poczet księży zamordowanych z pobudek politycznych lub przez ludzi związanych z obozem władzy był też ks. Stanisław Ziółkowski, który urodził się w Mierzanowicach w powiecie opatowskim. Zamordował go milicjant 23 września 1946 r. na kieleckiej Karczówce. Ks. Ziółkowskiego pochowano na cmentarzu w rodzinnej miejscowości. R. Gryz, Ziółkowski Stanisław (1904-1946), w: Leksykon duchowieństwa represjonowanego w PRL w latach 1945-1989. Pomordowani -więzieni-wygnani, red. J. Myszor przy współudziale J. Żurka, Warszawa 2003, s. 336-338.

79 R. Gryz, Państwo a Kościół..., dz. cyt., s. 108-114. Warto dodać, że parafia pw. św. Marcina Biskupa posiada księgi metrykalne: chrztów od 1615 r., zaślubionych od 1746 r. i zmarłych od 1696 r. Jubileuszowy Rocznik..., dz. cyt., s. 255.

${ }^{80}$ APK, Komitet Powiatowy Polskiej Zjednoczonej Partii Robotniczej [dalej: KP PZPR] w Opatowie, sygn. 34 (65/II/10), k. 105. 
aktu tzw. głosowaniem ludowym - referendum. Zorganizowano je 30 czerwca 1946 r. i odpowiednio „zabezpieczono”, propagując ideę głosowania „tak” na wszystkie trzy pytania dogodne dla dominujących komunistów. Monitorowaniem objęto także duchowieństwo, a zebrane dane objęły całe województwo kieleckie. Biskup Jan Lorek, aby uchronić duszpasterzy przed oskarżeniami o popieranie „reakcji”, polecił proboszczom skrócenie nabożeństw (podobnie uczynił tuż przed wyborami do Sejmu Ustawodawczego w styczniu 1947 r.). Zachowanie duchowieństwa było zróżnicowane. Taka sytuacja sprzyjała polityce podziału środowiska na księży „,pozytywnych” i „,negatywnych”, a w konsekwencji zróżnicowania polityki. Ministerstwo Informacji i Propagandy w Warszawie otrzymało informację o pozytywnym dla władz zachowaniu duchowieństwa w powiecie opatowskim. Pochlebnie wyrażano się o zakonnikach w Opatowie. Natomiast wyeksponowano „wyczyn księdza z parafii Kunów, (...) który po skończonym nabożeństwie zebrał parafian, udając się pochodem do biura głosowania, głosując jawnie na «tak» i nakazując wiernym iść za swoim przykładem. Wobec tego, iż tamtejszy obwód prawie w $100 \%$ głosował pozytywnie, inspektor z ministerstwa zaproponował wyasygnowanie odpowiedniej kwoty jako ofiary na kościół w Kunowie lub coś w tym rodzaju"»1. Postulat urzędnika dowodzi, że władzom państwowym zależało na rozbiciu jedności Kościoła przy użyciu różnych środków i metod, nie wyłączając materialnych zachęt.

Podczas kwerendy nie odnaleziono informacji szczegółowych dotyczących zachowania opatowskich duchownych w dniu wyborów do Sejmu Ustawodawczego 19 stycznia 1947 r. Przyjęli więc prawdopodobnie postawę neutralną, jak większość konfratrów. Nie zaangażowali się w „akcji wyborczej”, ani w „komitetach obywatelskich", ani nie znaleźli się wśród piętnowanych za antyrządowe wystąpienia ${ }^{82}$.

W pierwszych miesiącach po zakończeniu II wojny światowej na Kielecczyźnie mnożyły się incydenty związane ze święceniem sztandarów partii politycznych oraz ich obecnością na nabożeństwach. Generalnie rzecz ujmując Kościół odnosił się przychylnie do poświęcania sztandarów opozycyjnego wobec komunistów Polskiego Stronnictwa Ludowego (PSL), a zwłaszcza chadeckiej partii Stronnictwo Pracy (SP). W końcu stycznia 1946 r. zalegalizowany został Zarząd Powiatowy SP w Opatowie, ale nie przejawiał on większej aktywności, a sama partia, po sfałszowanym referendum, została w całym kraju zawieszona ${ }^{83}$. Księża inaczej ustosunkowywali się do inicjatyw innych partii, zwłaszcza Polskiej Partii Robotniczej, która opierała się na ideologii marksistowskiego materializmu. Ks. Czesław Florkiewicz wikariusz

81 A. Krawczyk, Pierwsza próba indoktrynacji. Działalność Ministerstwa Informacji i Propagandy w latach 1944-1947, Warszawa 1994, s. 90.

82 R. Gryz, Państwo a Kościót..., dz. cyt., s. 154-158.

83 W województwie kieleckim najbardziej aktywni byli członkowie Stronnictwa Pracy w Częstochowie. W. Bujak, Historia Stronnictwa Pracy: 1937, 1946, 1950, Warszawa 1988, s. 150. R. Gryz, Państwo a Kościół..., dz. cyt., s. 96-99. Zob. AAN, Komitet Centralny Polskiej Partii Robotniczej [dalej: KC PPR], sygn. 295/VII-259, k. 11. 
z Opatowa nie wpuścił do kościoła sztandaru PPR. Właśnie z tego powodu w Powiatowym Oddziale Informacji i Propagandy w Opatowie sformułowano wniosek, aby tego prefekta pozbawić prawa nauczania religii ${ }^{84}$. Wobec wzrastającego napięcia władze kościelne dążyły do całkowitego wyeliminowania obecności partyjnych sztandarów na mszach, przypominając księżom stosowne zarządzenia w tej sprawie ${ }^{85}$. W ten sposób chciano uniknąć niebezpiecznych reperkusji.

Zlikwidowanie chadeckiego nurtu w SP w połowie 1946 r. i wyjazd z Polski lidera PSL Stanisława Mikołajczyka w październiku 1947 r. spowodowały, że na scenie politycznej głównym wrogiem dla PPR stał się Kościół katolicki. Dyrektor V Departamentu Ministerstwa Bezpieczeństwa Publicznego (MBP) Julia Brystygierowa na specjalnej odprawie w ministerstwie wygłosiła wtedy referat zatytułowany „Ofensywa kleru a nasze zadania”. Przyszłość pokazała, że był to do końca PRL aktualny program walki z Kościołem. Szef WUBP w Kielcach Józef Pluta podał wykładnię tego projektu oznajmiając funkcjonariuszom: „Staje przed nami walka z klerem i my ją przyjmiemy, ale nie wolno nam tej walki przegrać, więc musimy poważnie się zastanowić nad jej formami. Towarzysze wypowiadając się na ten temat, żądali postawienia kropki nad i. Tak nie można. Naszym pierwszym zadaniem jest poznanie wroga, bo gdy go poznamy, przestanie być dla nas straszny. Trzeba mówić naszym towarzyszom co to jest kler. Należy szanować uczucia religijne wszystkich ludzi (...). Dziś polityka kleru zmierza do tego, żebyśmy my ich wyzwali do walki, ale to byłaby woda na młyn rozpolitykowanego kleru. (...) Musimy dobić PSL, by mieć zaplecze oczyszczone. Gdy tego dokonamy i gdy nasze szeregi partyjne będą ideologicznie dobrze uzbrojone, będziemy mieli szanse wygrania walki z klerem" ${ }^{\prime 86}$.

W kolejnych latach polityka władz świeckich zmierzała do ograniczenia społecznych wpływów Kościoła. W szkołach promowano przynależność do prokomunistycznego Związku Walki Młodych, a od lipca 1948 r. Związku Młodzieży Polskiej. Jan Kozłowski, I sekretarz KW PZPR w Kielcach, zapowiadał otoczenie młodzieży „ojcowską opieką partyjną"87, a nieco później mówił o „wypychaniu ich [duchowieństwa] z mieszkań, ze szkół, ze szpitali itd.(...)"88. W 1949 r. przeprowadzono ostrą nagonkę propagandową na Kościół i dokonano zmian przepisów prawnych,

${ }^{84}$ APK, Wojewódzki Urząd Informacji i Propagandy, sygn. 36, k. 83; R. Gryz, Państwo a Kościół..., dz. cyt., s. 153. Ks. Czesław Florkiewicz miał później problemy z nauczaniem religii także w Sandomierzu, gdzie był prefektem w Liceum Pedagogicznym i Szkole Ćwiczeń. W połowie 1950 r. znalazł się on w gronie sześciu etatowych księży nauczających religii, których władze oświatowe usunęły z pracy. W obronie prefektów wystąpił w czerwcu tego roku biskup sandomierski Jan Kanty Lorek w piśmie skierowanym do powołanego parę tygodni wcześniej w Warszawie Urzędu do Spraw Wyznań. AAN, UdSW, sygn. 5a/15, Pismo bp. J. Lorka do UdSW, Sandomierz, 22 VI 1950 r.

85 R. Gryz, Państwo a Kościól..., dz. cyt., s. 154.

86 AAN, KC PPR, sygn. 295/IX-149, k. 44.

87 Cyt. za: R. Gryz, Państwo a kościół..., dz. cyt., s. 180.

88 Cyt. za: R. Gryz, Państwo a kościół..., dz. cyt., s. 184. 
które uderzały w prawo do wolności sumienia i wyznania. Najpierw rząd wydał antykościelne oświadczenie z 14 marca 1949 r., w którym mówiono o poparciu dla duchownych lojalnych wobec władz i zwalczaniu przeciwnie ustosunkowanych. Informacje nagłaśniano na terenie całego kraju. Akcja zdawała się jednak przynosić odwrotne skutki od zamierzonych. W rejonie opatowskim przedstawiciel administracji państwowej obwiniał księży o rozpowszechnianie pogłosek, że „w krótkim czasie będą likwidowane kościoły i wiara chrześcijańska nie będzie miała uznania" ${ }^{89}$.

Bardzo ważnym polem konfliktu między władzami Polski „ludowej” a Kościołem była sprawa obecności religii w szkołach. Dotyczyła ona nie tylko nauczania tego przedmiotu, ale szerszej obecności wiary w edukacji młodego pokolenia ${ }^{90}$. Po wojnie religia była $w$ szkołach polskich nadobowiązkowym przedmiotem nauczania. Korzystając z danych z 1949 r. można stwierdzić, że parafia w Opatowie objęła wtedy edukacją religijną 1800 dzieci i młodzieży z wszystkich 11 szkół. Tygodniowy wymiar godzin religii wynosił 130, z których 85 prowadzili księża prefekci9 ${ }^{91}$. Problemy z nauczaniem religii w Opatowie nie dotyczyły tylko ks. Czesława Florkiewicza, który zmienił parafię w 1946 r. Potem było coraz gorzej. Widoczne było to w trakcie propagandowej tzw. akcji pokojowej, służącej rozwinięciu szeregów duchownych przychylnych władzy państwowej oraz podczas reperkusji, którymi dotknięci zostali ci duchowni, którzy nie podpisali tzw. apelu sztokholmskiego ${ }^{92}$. Władze państwowe uznały, że kto nie podpisał dokumentu opowiada się nie za pokojem lecz za wojną i wobec tego ten nie może uczyć w szkole. W tej sytuacji represje dotknęly wówczas ks. Stanisława Turzyńskiego. Opatowskiego prefekta pozbawiono prawa nauczania religii w szkołach i zwolniono z pracy w oświacie w $1950 \mathrm{r} \cdot{ }^{93}$ RdSW przy PWRN w Kielcach doniósł UdSW w Warszawie, że księża z opatowskiego „nie przejawiali czynnego udziału w akcji zbierania podpisów" "94. Okazało się, że w niektórych gromadach powiatu opatowskiego zdołano zebrać ledwie dwa, trzy podpisy ${ }^{95}$. Oznaczało to totalne fiasko propagandowej akcji w tym rejonie.

Pomimo poszukiwań nie odnaleziono dokumentów świadczących o próbach z końca lat 40. XX w. przekształcenia opatowskich szkół w placówki pod patronatem Towarzystwa Przyjaciół Dzieci. Nie mniej jednak w wyniku takich procedur zeświec-

89 APK, Urząd Wojewódzki Kielecki II, sygn. 1385, k. 15.

90 S. Bober, Walka o dusze dzieci i młodzieży w pierwszym dwudziestoleciu Polski Ludowej, Lublin 2011; H. Konopka, Religia w szkołach Polski Ludowej. Sprawa nauczania religii w polityce państwa (1944-1961), Białystok 1995.

${ }^{91}$ ADS, Akta Wizytacji Pasterskiej 1942-1951, Protokół wizytacji kanonicznej parafii św. Marcina w Opatowie, Opatów, 4 VI 1949 r.

92 Apel sztokholmski-zob.: H. Konopka, A. Konopka, Leksykon historii Polski po II wojnie światowej 1944-1997, Warszawa 1999, s. 16-17.

93 B. Stanaszek, Diecezja sandomierska..., dz. cyt., t. 1, s. 196.

94 AAN, UdSW, sygn. 5a/17, Pismo RdSW przy PWRN w Kielcach do UdSW z 6 IX 1950 r.

95 APK, KW PZPR, sygn. 54/IV-9, Protokół nr 26/50 z posiedzenia Egzekutywy KW PZPR w Kielcach 1 VII 1950 r. 
czono szereg szkół w województwie kieleckim. Proces polegał na zdejmowaniu krzyży ze ścian, usuwaniu nauki religii, zakazie modlitw w szkołach i udziału w rekolekcjach. Nie spotkano informacji źródłowych, które informowałyby o incydentach na tle nauczania religii w Liceum Ogólnokształcącym w Opatowie oraz w trzech szkołach powszechnych (siedmioklasowych) ${ }^{96}$. W okresie stalinowskim systematycznie spadała jednak liczba szkół publicznych z nauką religii oraz zatrudnionych katechetów. W roku szkolnym 1955/56 w województwie kieleckim nie nauczano tego przedmiotu w 65\% placówek, zaś w powiecie opatowskim wskaźnik ten był nawet niższy i wyniósł 56\%. Spadała też liczba księży prefektów. W powiecie opatowskim było ich jeszcze 37, co dawało temu powiatowi drugie miejsce po powiecie kieleckim (39). Rzecz interesująca, że w niektórych powiatach zachowały się tylko pojedyncze etaty (powiat Włoszczowa -6 , powiat Zwoleń - 1) ${ }^{97}$. W przypadku szkół średnich ogólnokształcących zarówno w Liceum Ogólnokształcącym w Opatowie jak i w Ostrowcu Świętokrzyskim nie nauczano w tym okresie religii ${ }^{98}$. Zjawisko to wymuszało na władzach kościelnych tworzenie punktów katechetycznych, które zwalczał m.in. WdSW w Kielcach. Także w powiecie opatowskim księża zaczęli uczyć religii w kościołach i kaplicach, ale W większości w prywatnych domach ${ }^{99}$.

Polski Październik '56 zaowocował liberalizacją polityki wyznaniowej i religia wróciła do niemal wszystkich szkół publicznych jako przedmiot nadobowiązkowy. W końcu następnego roku szkolnego, tj. w czerwcu 1958 r. religii w opatowskich szkołach uczyli obaj księża prefekci (ks. Stanisław Bartoszewski i ks. Bogumił Orłowski) oraz dwaj ojcowie bernardyni ${ }^{100}$. Wkrótce przeprowadzono jednak tzw. akcję dekrucyfikacyjną, której w roku szkolnym 1958/59 towarzyszyła laicyzacja szkół zawodowych i liceów pedagogicznych. Ograniczanie edukacji religijnej w szkołach polegało też na redukcjach etatów katechetów. Dotknęły one najpierw duchowieństwo zakonne. Z zestawienia na koniec roku szkolnego 1959/60 wynika, że w diecezji sandomierskiej wśród siedmiu zakonników-katechetów znalazł się bernardyn w Opatowie ${ }^{101}$. W notatce z września 1958 r. jeden z referentów WdSW w Kielcach napisał: „Szczególnie aktywną działalność (...) przejawiają zakonnicy ze zgromadzenia OO. Bernardynów w pracy z młodzieżą. Stosują oni różne atrakcyjne metody działania, jak np. wyświetlają filmy przeznaczone dla młodzieży, organizują różne ciekawe imprezy sportowe, w okresach uroczystych świąt kościelnych urządzają przedstawienia teatralne, w których dość pokaźny udział bierze młodzież. (...) Nie stwierdzono, aby zgromadzenie to prowadziło jakąkolwiek działalność po-

96 Rocznik... 1958 r., s. 68.

97 R. Gryz, Państwo a Kościót..., dz. cyt., s. 353, 356.

98 B. Stanaszek, Diecezja sandomierska..., dz. cyt., t. 2, s. 215.

99 R. Gryz, Państwo a Kościót..., dz. cyt., s. 357.

${ }^{100}$ ADS, Akta Wizytacji Pasterskiej 1962-1969, Uwierzytelniony odpis protokołu wizytacji pasterskiej przeprowadzonej 7 VI 1958 r. w parafii Opatów, Opatów, 8 VI 1958 r.

${ }^{101}$ B. Stanaszek, Diecezja sandomierska..., dz. cyt., t. 2, s. 227; APK, UW WdSW, sygn. 413, k. 3 . 
lityczną, jego głównym zainteresowaniem jest praca dewocyjna zmierzająca do pobudzenia życia religijnego wśród miejscowego społeczeństwa i na tym odcinku ma ono osiągnięcia"102.

Podczas wakacji w 1961 r. definitywnie usunięto religię ze szkół w Polsce w drodze ustawowej. Kościół powrócił do edukacji dzieci i młodzieży szkolnej w punktach katechetycznych. $\mathrm{Z}$ tego powodu władze zmierzały do roztoczenia nad nimi kontroli. Najpierw uwagę skupiono na punktach, które mieściły się w obiektach państwowych. Pojawiły się zachęty finansowe dla księży rejestrujących punkty katechetyczne. Takie umowy podpisywali głównie członkowie prorządowej grupy KK „Caritas”. Na początku 1963 r. powiat opatowski należał do tych, gdzie rejestracja objęła $100 \%$ tych miejsc. Księża ulegli więc presji. Równocześnie okazało się, że w tym rejonie diecezji była bardzo wysoka frekwencja uczniów na tych pozaszkolnych zajęciach ${ }^{103}$. Potwierdzają to wnioski z wizytacji w 1964 r., gdzie mowa o „dość dobrej” frekwencji dzieci, uczęszczających na religię w punktach katechetycznych przy wikariacie, w kościele OO. Bernardynów i w dwóch punktach poza miastem ${ }^{104}$.

Polityka antykościelna wymierzona była w szereg innych sfer działalności Kościoła. Należały do nich katolickie stowarzyszenia. W sierpniu 1949 r. wprowadzono dekret o stowarzyszeniach, który zobowiązywał do rejestracji katolickie stowarzyszenia. Kościół na to nie przystał z obawy przed inwigilacją stowarzyszonych. W Opatowie nie działało ich zbyt wielu, albo brak wiarygodnych informacji na ten temat. Z ewidencji zamieszczonej w Roczniku Diecezji Sandomierskiej za rok 1948 wymieniono jedynie Tercjarzy (71 osób), Straż Honorową i Żywy Różaniec ${ }^{105}$. Nie informowano o działalności organizacji dziecięcych czy młodzieżowych takich jak: Krucjata Eucharystyczna, Sodalicja Mariańska, Katolickie Stowarzyszenie Młodzieży Męskiej, czy Katolickie Stowarzyszenie Młodzieży Żeńskiej. Dysponujemy jednak danymi z protokołu wizytacji kanonicznej parafii św. Marcina z czerwca 1949 r., a w nim znajdują się brakujące informacje. Kół Żywego Różańca było 14 (w tym

${ }^{102}$ APK, UW WdSW, sygn. 413, k. 3.

${ }^{103}$ B. Stanaszek, Diecezja sandomierska..., dz. cyt., t. 2, s. 253, 257.

${ }^{104}$ ADS, Akta Wizytacji Pasterskiej 1962-1969, Protokół wizytacji pasterskiej odbytej w parafii Opatów przez J.E. Ks. Biskupa D-ra Piotra Gołębiowskiego 20 VI 1964 r. Zob. APK, UW WdSW, sygn. 214, k. 6-7. Początkowo starano się zastraszyć zakonników, aby nie prowadzili punktu katechetycznego. Okazało się to nieskuteczne, mimo przeprowadzenia państwowej wizytacji w klasztorze 19 września 1962 r. W protokole zapisano wtedy m.in.: „Zakonnicy posiadają dość duży wpływ na miejscowe społeczeństwo. Oddziaływanie mają oni ułatwione poprzez prowadzenie punktu katechetycznego w klasztorze oraz przez systematyczne duszpasterstwo. W ubiegłym roku Przewodniczący Prezydium PRN rozmawiał z przełożonym o. [Robertem Stanisławem] Markiem i zabronił mu prowadzenia punktu katechetycznego. Zakonnicy do tego nie zastosowali się i prowadzili nadal naukę religii. W roku bieżącym również rozpoczęli nauczanie. Decyzji na piśmie nie wydawano z tych względów, że realnie nie będą one wykonalne w tych warunkach". APK, UW WdSW, sygn. 413, k. 15.

${ }^{105}$ Rocznik... 1948 r., s. 62. 
jedno - ojców i 2 - panien), Trzeci Zakon obejmował 75 osób (w tym 2 mężczyzn), Krucjata Eucharystyczna gromadziła 70 członków, a Koło Ministrantów 22 chłopców. Przy kolegiacie istniał też parafialny oddział „Caritas”"106.

Ten ostatni jednak przestał działać na początku $1950 \mathrm{r}$. Wtedy władze państwowe istotnie uszczupliły kościelny stan posiadania. Poprzez zabór instytucji i mienia Kościoła katolickiego planowano ograniczyć możliwości społecznych wpływów ideologicznego przeciwnika. Przyspieszenie tych działań zaczęło się od upaństwowienia Caritasu 23 stycznia 1950 r., kiedy utworzono Zarząd Przymusowy Zrzeszenia Caritas. Zarząd Główny tej organizacji w dwa dni później utworzył w poszczególnych regionach kraju zarządy wojewódzkie. W skład Zarządu Wojewódzkiego Caritas w Kielcach weszły początkowo 23 osoby, w tym 10 księży. Tylko dwóch z nich pochodziło z diecezji sandomierskiej, a pozostali z kieleckiej. Funkcję prezesa objął wspominany ks. Stanisław Skurski. Tegoż duchownego zwerbowano także do pracy w Zarządzie Głównym Caritasu ${ }^{107}$. Podczas dalszego prowadzenia „akcji Caritas” władzom państwowym nie udało się powstrzymać fali zamykania parafialnych oddziałów tej dobroczynnej organizacji. Tak też stało się w Opatowie, gdzie parafialny oddział Caritas dobrze się rozwija1 ${ }^{108}$. W Przymusowym Zarządzie Diecezjalnym Caritas w Sandomierzu księża nie chcieli uczestniczyć. W skali diecezji zaledwie kilka zarządów parafialnych podjęło współpracę z państwem, stąd konieczny był stały nadzór służb nad ich działalnością. O zaistniałej sytuacji wierni mieli usłyszeć ze specjalnego listu pasterskiego Episkopatu, którego odczytanie nastąpiło 12 lutego $1950 \mathrm{r}$. Władze dążyły do zablokowania tego zamiaru. Ks. Andrzej Glibowski z Opatowa znalazł się w wąskiej grupie czterech proboszczów z powiatu opatowskiego, którzy kategorycznie oświadczyli, że list odczytają. Władze państwowe oceniły ich, że są „najbardziej uparci i wrodzy (...), w żadnej akcji z nimi nie można dojść do porozumienia"109. Opatowscy duchowni odmówili współpracy z upaństwowionym Caritasem.

Kolejnym z serii antykościelnych posunięć była konfiskata tzw. dóbr „martwej ręki”, czyli nieruchomości ziemskich należących do związków wyznaniowych i w rezultacie utworzenie Funduszu Kościelnego. W skali kraju majątki te obejmowały ponad 147 tys. ha, ale w województwie kieleckim zaledwie 2,2 tys. ha. Na początku marca 1950 r. państwowym nadzorem w województwie kieleckim objęto zaledwie trzy majątki. Dwa z nich znajdowały się w powiecie opatowskim (Kobylany 516 ha i Lipowa 181 ha), a należały do Zgromadzenia Sióstr Miłosierdzia św. Wincentego á Paulo. Ustawa o przejęciu tzw. dóbr „martwej ręki”, poręczeniu

${ }^{106}$ ADS, Akta Wizytacji Pasterskiej 1942-1951, Protokół wizytacji kanonicznej parafii św. Marcina w Opatowie, Opatów, 4 VI 1949 r.

${ }^{107}$ R. Gryz, Państwo a Kościót..., dz. cyt., s. 246-247.

${ }^{108}$ Przykładowo w 1947 r. wysokie noty otrzymała organizacja kolonii letnich w Opatowie. Rocznik... 1952/53 r., s. 56; B. Stanaszek, Diecezja sandomierska..., dz. cyt., t. 2, s. 316-317.

${ }^{109}$ Cyt. za: B. Stanaszek, Diecezja sandomierska..., dz. cyt., t. 2, s. 322. Zob. R. Gryz, Państwo a Kościół..., dz. cyt., s. 249. 
proboszczom posiadania gospodarstw rolnych i utworzeniu państwowego Funduszu Kościelnego, spowodowała upaństwowienie wszelkich nieruchomości ziemskich związków wyznaniowych. Była to próba znaczącego ograniczenia autonomii Kościoła przez pozbawienie go jednego ze źródeł finansowania. W dodatku utworzenie Funduszu Kościelnego otworzyło drogę do finansowego wsparcia formacji prorządowych księży. Wyłączone z ustawy były gospodarstwa rolne proboszczów o powierzchni do 50 ha, gospodarstwa zakonne do 5 ha oraz posiadłości biskupów ordynariuszy i seminariów duchownych do 50 ha. Praktyka polegała jednak na wielokrotnym naruszaniu wysokości tych norm ${ }^{110}$. Na Kielecczyźnie wdrożenie nowych regulacji wobec kilkunastu posiadłości odbyło się bez większych przeszkód. W dobrach klasztornych skonfiskowano nawet te po kilka ha. Tak było w Wąchocku u cystersów $\left(2,2\right.$ ha) i w Opatowie u bernardynów, gdzie przejęto areał 2 ha ${ }^{111}$. Parafia św. Marcina zachowała ziemię o powierzchni 11 ha, z których prawie 4 ha zajmowały grunty rolne, 6,05 ha cmentarz i 0,95 ha pod budynkami ${ }^{112}$.

W kwietniu 1950 r. Episkopat Polski wraz z prymasem Stefanem Wyszyńskim zdecydował o podpisaniu z władzami państwowymi tzw. porozumienia. Pomimo to władze nadal dyskryminowały i zwalczały Kościół. W województwie kieleckim aresztowano kilkudziesięciu duchownych i położono podwaliny pod rozwój prorządowej formacji duchownych. Kolejne działania nie zniszczyły Kościoła, choć go osłabiły. W momencie apogeum stalinizmu w czerwcu 1953 r. w KC PZPR sformułowano następujący wniosek: „Sprawa przezwyciężenia wierzeń religijnych wśród szerokich mas - to sprawa dziesięcioleci" ${ }^{\prime 13}$. Z walki nie rezygnowano, ale zdawano sobie sprawę, że proces ograniczania i eliminacji Kościoła z życia publicznego będzie bardzo długi. Jednym z punktów tzw. porozumienia było zobowiązanie strony kościelnej, że nie będzie sabotowała akcji kolektywizacji rolnictwa. O tym, że było to bardzo trudne przedsięwzięcie mówili na jednej z narad przedstawiciele lokalnych struktur PZPR i ZSL (Zjednoczonego Stronnictwa Ludowego) w Opatowie 22 czerwca $1950 \mathrm{r}$. Wspominano o propagandzie antykołchozowej oraz przeciwnej zbieraniu podpisów pod Apelem Sztokholmskim ${ }^{114}$.

W roku słynnego pokazowego procesu biskupa kieleckiego Czesława Kaczmarka i aresztowania prymasa Stefana Wyszyńskiego przystąpiono do realizacji projektu rozbicia kleru katolickiego przy użyciu wspomnianego już dekretu Rady Państwa z 9 lutego 1953 r. o obsadzaniu duchownych stanowisk kościelnych. W związku z nim zmuszono wszystkich księży do złożenia w kilku turach ślubowania na wierność PRL ${ }^{115}$. W pierwszej turze nie dopuszczono do tego aktu m.in. ks. dziekana

\footnotetext{
${ }^{110}$ R. Gryz, Państwo a Kościót..., dz. cyt., s. 250-251.

111 AAN, Ministerstwo Administracji Publicznej, sygn. 671, k. 25-30.

${ }^{112}$ ADS, Akta Wizytacji Pasterskiej 1942-1951, Protokół wizytacji kanonicznej parafii św. Marcina w Opatowie, Opatów, 4 VI 1949 r.

${ }^{113}$ Cyt. za: R. Gryz, Państwo a Kościót..., dz. cyt., s. 309.

${ }^{114}$ APK, KP PZPR w Opatowie, sygn. 26 (65/II/2), k. 10-12.

${ }^{115}$ R. Gryz, Państwo a Kościót..., dz. cyt., s. 312-317.
} 
Andrzeja Glibowskiego ${ }^{116}$. Przystąpiono też do akcji usuwania z różnych stanowisk księży, którzy zostali zakwalifikowani do grupy wrogów ustroju. Podczas kwerendy nie natrafiono w źródłach na informacje świadczące o wystosowaniu takich wniosków w następnych latach wobec opatowskich proboszczów, poza opóźnieniem proboszczowskiej nominacji ks. Tomasza Zadęckiego w 1962 r.

Ważnym instrumentem stymulowania postaw duchownych była polityka podatkowa. Najbardziej dotkliwe zmiany wprowadzono na przełomie 1958 i 1959 r. (zarządzenie Ministerstwa Finansów z 10 grudnia 1958 r. o podatku dochodowym od lokali i okólnik tegoż ministerstwa z 25 lutego 1959 r. w sprawie podatku dochodowego od wydatków na cele inne niż kultu religijnego). Miały one spowodować niewypłacalność parafii. Proboszczów „pozytywnych” objęto systemem ulg. W świetle nowych zasad fiskalnych ks. Stanisław Szczepaniak z Opatowa, który w 1958 r. zapłacił 3960 zł podatku dochodowego, w następnym roku musiał uiścić 8488 zł należności. Ponadto otrzymał domiar podatkowy wyrównania do sumy $16000 \mathrm{z}^{117}$. W następnych latach nastąpiły kolejne odsłony wojny podatkowej, jako element zwalczania, jak mówiono w propagandzie „ofensywy wojującego klerykalizmu”, którym to mianem określono prymasowski program Wielkiej Nowenny Tysiąclecia ${ }^{118}$. Temu służyć miały także państwowe wizytacje w domach zakonnych. Przełożony opatowskich bernardynów o. Stanisław Marek zgodził się na taką lustrację 29 września 1962 r. Przeprowadziła ją komisja w składzie: Mieczysław Woś z WdSW w Kielcach, Władysław Kabała - kierownik Wydziału Spraw Wewnętrznych PPRN w Opatowie i Józef Zawisza - kierownik referatu wymiaru podatków i opłat w Wydziale Finansowym PPRN w Opatowie ${ }^{119}$. Pomimo wizytacji, wicedyrektor UdSW w Warszawie Jan Bohdan zalecał przeprowadzenie dalszych kontroli, gdyż jego zdaniem należało skorygować „w górę" wykazany dochód w księgach kasowych i ustalić hipoteczną własność nieruchomości klasztornych ${ }^{120}$. Przeprowadzona została nowa kalkulacja przychodów zgromadzenia, które dotychczas nie było opodatkowane. Za 1963 r. dochód z nieruchomości gruntowych (2,59 ha) wyliczono na 14180 zk, przychodu z lokali na 3100 zł, przychodu z tacy na rzecz parafii na 14210 zł, z intencji mszalnych na 15000 zł, z misji i rekolekcji na 8400 zł. Łącznie dało to sumę 54890 zł przychodów. Podatku albo nie naliczono w ogóle, albo był on minimalny, gdyż łączna suma wydatków klasztoru wyniosła 52098 zł ${ }^{121}$. Zysk wynosił więc 2792 zł.

W tym miejscu warto nawiązać do istniejącego wówczas problemu laicyzacji służby zdrowia w PRL. Obecność kapelanów i osób zakonnych w szpitalach oraz istnienie kaplic $w$ tych obiektach doskwierało władzom państwowym i partyjnym przez kolejne lata. W 1960 r. wzmogła się presja na redukcje wpływów Kościoła w tych

\footnotetext{
${ }^{116}$ B. Stanaszek, Diecezja sandomierska..., dz. cyt., t. 1, aneks 4.

${ }_{117}$ B. Stanaszek, Diecezja sandomierska..., dz. cyt., t. 1, s. 403-404.

118 Zob. APK, UW WdSW, sygn. 214, k. 12-13.

${ }^{119}$ APK, UW WdSW, sygn. 413, k. 13-16.

${ }^{120}$ APK, UW WdSW, sygn. 413, k. 30.

${ }^{121}$ APK, UW WdSW, sygn. 413, k. 32-35.
} 
placówkach opieki medycznej. W województwie kieleckim w 15 szpitalach zatrudnionych było 101 sióstr zakonnych. W Szpitalu Powiatowym w Opatowie pracowało pięć sióstr - szarytek. Aparatczycy partyjni zarzucali im organizowanie głośnych, zbiorowych modlitw w kaplicy i salach szpitalnych ${ }^{122}$. W następnych latach władze ograniczały zaangażowanie Kościoła w jego odpłatną posługę w szpitalach. W latach sześćdziesiątych trwało systematyczne zwalnianie sióstr z pracy w Szpitalu Powiatowym w Opatowie. Wszystkie zakonnice, bez względu na to czy pracowały jednocześnie w szpitalu czy nie, utrzymywały się z pensji sióstr tam zatrudnionych lub rent społecznych. W sprawozdaniu z kontroli zgromadzenia, jaką przedstawiciele władz państwowych przeprowadzili 8 marca 1963 r., stwierdzono m.in.: „Zakonnice cieszą się dużym autorytetem pracowników administracji szpitalnej oraz wśród pozostałego personelu lekarskiego. (...) Dyrektor szpitala ocenia pracę pielęgniarek zakonnych jako nadzwyczaj ofiarną. Uważa on, że personel świecki nie jest w stanie pracować tak ofiarnie mimo najszczerszych chęci. O siostrze [Eugenii] Gontarek wyraził wiele słów uznania. Podkreślił, że jest ona pod względem fachowym niezastąpiona. Bierze udział w każdej poważniejszej operacji. Ma duże doświadczenie i zrezygnowanie $\mathrm{z}$ niej przyniosłoby wiele szkody $\mathrm{w}$ pracy szpitala. (...) Zwolnione siostry użalały się, że mija blisko rok czasu i nie otrzymują renty mimo, że wszystkie dokumenty zostały przesłane do ZUS w Kielcach. (...) Ograniczenie oddziaływania sióstr zakonnych na szpital będzie można spowodować tylko przez ich dalsze zwalnianie z pracy i zatrudnianie na ich miejscu personelu świeckiego" ${ }^{\prime 23}$. Tak też się działo w następnych latach.

\section{Z życia religijnego w Opatowie}

Obraz życia religijnego zależał od aktywności duchowieństwa, stosunku do obowiązków religijnych samych wiernych oraz polityki władz państwowych, które wobec społeczeństwa nie przyjęły zasady neutralności światopoglądowej. Z protokołu wizytacji kanonicznej z 4 czerwca 1949 r. wynika, że w niedziele i święta jak też w dni powszednie w kolegiacie św. Marcina w Opatowie odprawiano po trzy Msze św. W dni świąteczne do udziału w nich zobowiązanych było około 6 tys. osób. Frekwencja wynosiła około 4,5 tys. osób, czyli swój obowiązek spełniało aż $75 \%$ wiernych. W poprzednim roku parafianie zamówili 632 Msze św. ${ }^{124}$, co oznaczało, że prawie każdego dnia odprawiano nabożeństwa w dwóch intencjach. W 1949 r. w parafii było około 10 dzieci bez sakramentu chrztu. W poprzednim roku do sakramentu eucharystii przystąpiło 175 dzieci. Wysoki był wskaźnik osób korzystających z sakramentu pokuty. Na około 6 tys. osób zobowiązanych przynajmniej w okresie Wielkanocy przystąpić do spowiedzi, zaledwie około 500 osób nie

${ }^{122}$ B. Stanaszek, Diecezja sandomierska..., dz. cyt., t. 2, s. 341.

${ }^{123}$ APK, UW WdSW, sygn. 415, k. 3-4. Sprawozdanie to trafiło do KW PZPR w Kielcach oraz Wydziału IV Służby Bezpieczeństwa w Kielcach. APK, UW WdSW, sygn. 415, k. 5.

${ }^{124}$ ADS, Akta Wizytacji Pasterskiej 1942-1951, Protokół wizytacji kanonicznej parafii św. Marcina w Opatowie, Opatów, 4 VI 1949 r. 
wypełniło tego obowiązku (8\%). Łącznie w całym 1948 r. rozdano około 24 tys. komunii św. Podczas wizytacji kanonicznej do sakramentu bierzmowania przystąpiło aż 1500 osób, głównie młodzieży. Interesujące dane określające poziom religijności w parafii Opatów w końcu lat czterdziestych XX w., dotyczą także udziału w najbardziej popularnych nabożeństwach dodatkowych. Były to zarówno nabożeństwa majowe jak i październikowe (różańcowe), w których uczestniczyło około 600 osób. Drogę Krzyżową przy udziale 300 osób odprawiano w kolegiacie w każdą niedzielę Wielkiego Postu, zaś w klasztorze w każdy piątek. W pierwsze piątki miesiąca do komunii przystępowało 100 osób, w tym 10 mężczyzn ${ }^{125}$.

Dysponujemy także charakterystyką parafii w Opatowie z początku lat 50. XX w., którą opracowali urzędnicy pionu wyznaniowego w Kielcach. W kartotece parafii zawarli dość lakoniczny zapis: „Ludność parafii ustosunkowana do kleru w 90\% pozytywnie, a 10\% obojętnie, natomiast młodzież z różnych szkół ustosunkowana do kleru w $100 \%$ pozytywnie. W przeorganizowanym „Caritasie” księża udziału nie biorą, ludność w 75\% rolnicza, w 25\% robotnicza, opodatkowania żadnego nie ma, są dobrowolne ofiary, odpusty odbywają się co roku 11-go listopada""126. Podane wskaźniki są szacunkowe. Niemniej jednak ten opis przede wszystkim potwierdza ogromne wpływy duchowe Kościoła katolickiego wśród społeczeństwa Opatowa.

W okresie stalinowskim władze partyjno-państwowe próbowały metodami administracyjnymi ograniczać zasięg praktyk religijnych (procesje, pielgrzymki). Skutki takiej polityki bywały odwrotne od zamierzonych. Pielgrzymka z Opatowa na odpust w Sulisławicach ${ }^{127}$ w dniu 8 września 1954 r. objęła kilkaset osób. Prawdopodobnie dlatego we wrześniu następnego roku decydenci odmówili parafianom z Opatowa zgody na pielgrzymkę do Sulisławic ${ }^{128}$. Podobnie postąpiono w stosunku do Modliborzyc w powiecie opatowskim. Tamtejsi parafianie jednak wyruszyli na pątniczy szlak wbrew tej decyzji. Do Wojewódzkiego Urzędu do Spraw Bezpieczeństwa Publicznego w Kielcach dotarła informacja, że pielgrzymi idąc przez kolejne wioski śpiewali pieśń My chcemy Boga ${ }^{129}$. Ograniczenia w wydawaniu pozwoleń powodowały, że pielgrzymki przybierały postać antysystemowych manifestacji, ale do niektórych pielgrzymek w ogóle nie doszło. W Opatowie w 1963 r. zdołano np. nie dopuścić do zorganizowanych i grupowych wyjazdów pielęgniarek i lekarzy w ramach pielgrzymek pracowników służby zdrowia na Jasną Góręę ${ }^{130}$.

${ }^{125}$ ADS, Akta Wizytacji Pasterskiej 1942-1951, Protokół wizytacji kanonicznej parafii św. Marcina w Opatowie, Opatów, 4 VI 1949 r.

${ }^{126}$ APK, UW WdSW, sygn. 214, k. 1.

${ }^{127}$ Sanktuarium w Sulisławicach było szczególnym miejscem na pątniczym szlaku, cieszącym się bardzo dużą frekwencją. Funkcjonariusze UB obserwowali to miejsce i raportowali do WUBP w Kielcach o przebiegu uroczystości. Brali w nich udział także mieszkańcy Opatowa i powiatu opatowskiego. K. Fedorowski, Represje..., dz. cyt., s. 109, 126, 168, 172.

${ }^{128}$ B. Stanaszek, Diecezja sandomierska..., dz. cyt., t. 2, s. 74-75.

${ }^{129}$ R. Gryz, Państwo a Kościót..., dz. cyt., s. 365.

${ }^{130}$ B. Stanaszek, Diecezja sandomierska..., dz. cyt., t. 2, s. 345. 
Uroczystością otoczoną specjalną troską służb specjalnych i państwowej administracji do spraw wyznań były powitania biskupów podczas wizytacji kanonicznej parafii. Atmosfera była wtedy bardzo podniosła i wierni wraz z duchowieństwem uznawali tę okoliczność za specjalną. Przygotowywano bramy powitalne, banderie konne, dekoracje miejscowości, przemówienia delegacji. Biskup Jan Lorek akcentował duchowy charakter wizytacji kanonicznych i nie zalecał budowy powitalnych bram, aczkolwiek były to dowody świadczące o przywiązaniu katolików do wiary i Kościoła. Jednocześnie - w odbiorze władz świeckich - potwierdzano bardzo ograniczone efekty prowadzonej przez kolejne lata indoktrynacji i ograniczania społecznego oddziaływania Kościoła. Argumentem dla tej tezy odnoszącym się do Opatowa jest wspominana już wizytacja kanoniczna z 1949 r. „Chcąc odciągnąć pewną ilość ludzi - czytamy w uwierzytelnionym odpisie dodatku do protokołu z wizytacji - od wzięcia udziału w powitaniu biskupa, zarządziło Starostwo [Powiatowe w Opatowie - R.G.] szarwarkowe roboty na boisku. Mimo to była i banderja [tak w tekście - R.G.] i spora ilość wiernych, nie mogących pomieścić się w świątyni. Cały przebieg uroczystości wizytacyjnych odbył się godnie i thumnie mimo tzw. Święta ludowego" "131. Podczas uroczystości w Opatowie 25 czerwca 1955 r., przemawiający w imieniu dzieci i starszych ,wykazywali przywiązanie do wiary w Boga, do kościoła [tak w tekście - R.G.], dawali przyrzeczenia, że od wiary w Boga nie odstąpią, prosząc biskupa o błogosławieństwo"132. Warto zacytować fragment protokołu z wizytacji kanonicznej z 1958 r., gdzie biskup Lorek relacjonował przebieg drugiego dnia wizytacji: „Dnia 8 czerwca 1958 r. o godzinie 8 rano przybyłem do Opatowa w celu dopełnienia wizytacji pasterskiej. Przy bramie cmentarza kościelnego zebrali się licznie wierni pod przewodnictwem kilkunastu kapłanów. Przedstawiciele parafian starszych, młodzieży i dzieci wygłosili przemówienia powitalne. W kościele serdecznie powitał mnie ks. kan. Stanisław Szczepaniak, pełniący obowiązki duszpasterskie przy Kolegiacie Opatowskiej od 1957 r. Odprawiłem Mszę św. i przemówiłem do licznie zebranej młodzieży, następnie udzieliłem Sakramentu Bierzmowania, do którego przystąpiło 279 osób"133.

Nowenna do św. Stanisława Kostki zorganizowana dla dzieci i młodzieży na początku listopada 1955 r. była także powodem niepokojów dla władz partyjno-państwowych. Duchowni apelowali w kazaniach, aby młodzież naśladowała swego patrona, który oddał całe swe życie dla chwały Boga. Referat Organizacji Masowych

${ }^{131}$ ADS, Akta Wizytacji Pasterskiej 1942-1951, Uwierzytelniony odpis dodatku do protokołu z wizytacji kanonicznej parafii św. Marcina w Opatowie z 4 VI 1949 r. [data odpisu 12 XII 1950 r.]. Biskup Jan Lorek w czasie tej wizytacji wybrał się także do klasztoru OO Bernardynów, gdzie przebywało 3 zakonników i 2 braci. Mógł przekonać się o trwających tam pracach zabezpieczających budowle przed zrujnowaniem. Odwiedził chorych w opatowskim szpitalu.

${ }^{132}$ Cyt. za: B. Stanaszek, Diecezja sandomierska..., dz. cyt., t. 2, s. 179.

${ }^{133}$ ADS, Akta Wizytacji Pasterskiej 1962-1969, Uwierzytelniony odpis protokołu wizytacji pasterskiej przeprowadzonej 7 VI 1958 r. w parafii Opatów, Opatów, 8 VI 1958 r. 
przy KW PZPR w Kielcach otrzymał informację, że księża w Opatowie wykorzystywali obecność młodzieży na nabożeństwach w rekrutacji do kółek ministrantów ${ }^{134}$.

Rozwój życia religijnego władze państwowe wielokrotnie starały się deprecjonować poprzez nadawanie mu charakteru dewocyjnego i fanatycznego. Po zakończeniu centralnych uroczystości Roku Maryjnego na Jasnej Górze w Częstochowie (26 sierpnia 1956 r.), kieleckie władze bezpieczeństwa zanotowały w ciągu kilku dni 10 wypadków rzekomych cudów polegających na odnawianiu się obrazów Matki Boskiej Częstochowskiej. Spośród nich 7 przypadało na pow. kielecki, 2 opatowski i 1 starachowicki. Stwierdzano, że informacje o rzekomych cudach rozpowszechniane były głównie przez „małorolnych chłopów sfanatyzowanych na tle religii”. Kontrakcja polegała na bezpośrednim wyjaśnianiu, krytyce na łamach prasy, przeciwdziałaniu księży, którzy byli nakłaniani do tego przez powiatowe RdSW ${ }^{135}$.

Próby ograniczania religijności obywateli polegały także na piętnowaniu takich postaw wśród funkcjonariuszy aparatu partyjno-państwowego. W każdym okresie PRL partia przykładała do tego dużą uwagę. O ile „religianctwo” było tolerowane w przypadku szeregowych członków PZPR, o tyle pracownicy aparatu partyjnego lub Służby Bezpieczeństwa byli karani za takie postawy. Przykładem piętnowania tego rodzaju sytuacji niech będzie sprawa jednego z sekretarzy Komitetu Powiatowego PZPR w Opatowie, który w 1956 r. wziął nocą ślub w kościele poza miastem. Taką informacją dysponował KP PZPR w Sandomierzu, powołując się na tego typu działalność proboszcza z Włostowa w dekanacie opatowskim ${ }^{136}$. Ze względu na groteskowy charakter przedsięwzięcia przywołajmy w tym miejscu także pomysł ks. Władysław Rączkiewicza z Modliborzyc koło Opatowa, który zaangażował do odegrania roli diabła w parafialnych jasełkach sekretarza tamtejszej Podstawowej Organizacji Partyjnej (sic! $)^{137}$. Pomińmy tutaj szerszy komentarz, gdyż nie można mieć pewności co do kwestii motywacji obu osób przy tym działaniu.

Podobnie rzecz się miała $\mathrm{z}$ kościelnymi inwestycjami budowlanymi. W sierpniu 1953 r. proboszcz z Piórkowa w powiecie opatowskim nie uzyskał pozwolenia na rozbudowę kościoła. Wojewódzki Zespół Organizacji Masowych (WZOM) przy KW PZPR w Kielcach uznał bowiem, że do parafii należą ledwie dwie gromady i planowane prace potraktowano jako niecelowe ${ }^{138}$. Pomimo to parafianie doprowadzili tam do powiększenia kościoła w 1955 r. ${ }^{139} \mathrm{Z}$ kolei w Biskupicach należących do parafii św. Marcina w Opatowie zatrzymano budowę kaplicy, a zgromadzone materiały budowlane posta-

\footnotetext{
${ }^{134}$ APK, KW PZPR, sygn. 3662, k. 133.

${ }^{135}$ Biuro Ewidencji i Archiwum Urzędu Ochrony Państwa, sygn. XXX/D/1, Informacja WUdSBP w Kielcach do Gabinetu Przewodniczącego KdSBP w Warszawie z 5 IX 1956 r.; Biuro Ewidencji i Archiwum Urzędu Ochrony Państwa, sygn. XXX/D/1, Sprawozdanie z pracy Wydziału VI WUdSBP w Kielcach za III kwartał 1956 r.

${ }^{136}$ B. Stanaszek, Diecezja sandomierska..., dz. cyt., t. 2, s. 348.

${ }^{137}$ B. Stanaszek, Diecezja sandomierska..., dz. cyt., t. 2, s. 350-351.

${ }^{138}$ R. Gryz, Państwo a Kościół..., dz. cyt., s. 367.

${ }^{139}$ Rocznik... 1958 r., s. 110.
} 
nowiono przeznaczyć na budowę szkoły. Władze wojewódzkie z Kielc łącznie z włodarzami powiatu opatowskiego miały na miejscu uzgodnić takie ich przekazanie, ,aby wniosek wyszedł oddolnie"140. Plany prawdopodobnie nie ziściły się, gdyż 23 grudnia 1955 r. Wojewódzki Zespół Organizacji Wydzielonych przy KW PZPR w Kielcach zaaprobował wniosek biskupa Jana Lorka i stanowisko administratora w Biskupicach objął ks. Czesław Tatar. Pracę duszpasterską prowadził on wśród niemal 1500 wiernych w drewnianym kościele zbudowanym w 1954 r. Parafię erygowano tam - o czym już wspomniano - w 1957 r., ale jej faktyczne funkcjonowanie miało swój początek kilka lat wcześniej. Być może zdecydowało o tym stanowisko samego kierownika Wydziału Organizacji Masowych KC PZPR w Warszawie Stanisława Pawlaka (związanego wcześniej z KW PZPR w Kielcach), który w 1953 r. polecił wydać zezwolenie na budowę kaplicy. Sprawę wsparł też ks. Skurski. Ksiądz Bogdan Stanaszek podał w jednym ze swych artykułów informację, że zarówno pozwolenie na budowę kościoła w Biskupicach, jak i na erygowanie parafii w tej miejscowości wydano ,ze względu na postawę" ks. Andrzeja Glibowskiego. Należy w tym momencie podkreślić, że był to jeden z nielicznych przypadków zbudowania nowego obiektu sakralnego w województwie kieleckim w latach 1950-1956 w oparciu o zgodę wymuszoną na władzach świeckich ${ }^{141}$.

Coroczna organizacja procesji Bożego Ciała przysparzała duchowieństwu parafialnemu wielu problemów. Władze świeckie próbowały ograniczać manifestacje wiary decyzjami administracyjnymi dotyczącymi przebiegu tras procesji ulicami danej miejscowości. W przypadku Opatowa pozostał ślad w dokumentach świadczący o tym, że w czerwcu 1958 r. tamtejszy proboszcz i dziekan ks. Stanisław Szczepaniak należał do grupy duchownych, którzy nie uzgodnili z władzami państwowymi trasy procesji. W związku z tym otrzymał on upomnienie na piśmie z WdSW w Kielcach, a o sprawie powiadomiony został nawet UdSW w Warszawie ${ }^{142}$. W $1963 \mathrm{r}$. ks. Tomasz Zadęcki stwierdził w kazaniu podczas uroczystości Bożego Ciała w Opatowie, że władze państwowe organizują młodzieży wycieczki, aby spowodować jej absencję na uroczystościach kościelnych ${ }^{143}$.

Istotnie, władze PRL przykładały wielką uwagę do kontroli działalności kaznodziejskiej duchownych, która miała wybitny wpływ na rozwój życia religijnego. Bezpośrednią inwigilację kazań prowadzili funkcjonariusze bezpieki, milicji i pra-

${ }^{140}$ Cyt. za: R. Gryz, Państwo a Kościót..., dz. cyt., s. 367.

${ }^{141}$ B. Stanaszek, Budownictwo kościelne w diecezji sandomierskiej w latach 1945-1970, „Studia Sandomierskie" 9 (2002), s. 415-416. Informacje o początkach parafii w Biskupicach zob.: APK, KW PZPR, sygn. 54/VIII-204, Protokół nr 8 z posiedzenia WZOW 23 XII 1955 r.; Rocznik... 1958 r., s. 65; APK, KW PZPR, sygn. 54/VI-24, Wykaz obiektów sakralnych i kościelnych wzniesionych w woj. kieleckim w latach 1945-1956; Dokument PZPR o działaniach wobec Kościoła katolickiego w województwie kieleckim w 1953 roku, oprac. G. Miernik, „Studia Kieleckie”, seria historyczna, 1995, nr 1, s. 60; B. Stanaszek, Diecezja sandomierska..., dz. cyt., t. 1, s. 514-516.

${ }_{142}$ B. Stanaszek, Diecezja sandomierska..., dz. cyt., t. 2, s. 55.

${ }^{143}$ B. Stanaszek, Diecezja sandomierska..., dz. cyt., t. 2, s. 61. 
cownicy innych urzędów i instytucji państwowych od 1945 r. Wypowiedzi księży z ambony były klasyfikowane i wpływały na dalsze działania operacyjne. „Wrogie” kazania odnotowywano także wielokrotnie w Opatowie. Do wypowiadających je na początku lat sześćdziesiątych zaliczono gwardiana bernardynów w Opatowie o. Stanisława Marka. Sprawą jego wrogich wystąpień podczas kazań zajmowało się SB w Ostrowcu Świętokrzyskim (1962) ${ }^{144}$.

Programowi laicyzacji czy ateizacji przeciwdziałali duchowni. Biskup sandomierski oceniał skuteczność ich działań po kilkunastu latach od zakończenia wojny w następujących słowach: „Parafianie opatowscy są religijni, lecz niezbyt gorliwi. W 1957 r. na 7957 parafian rozdano w kolegiacie, w klasztorze i w kaplicy szpitala razem 37950 komunii św. Jest to liczba za mała. 22 pary żyją bez ślubu kościelnego w publicznym konkubinacie. Dwie rodziny zaniedbują chrzest dzieci. Pewna ilość mężczyzn, głównie z miasta Opatowa, z opieszałości nie przystępuje do Sakramentów św. Z wad do najbardziej rażących należy pijaństwo. Życie religijne parafian opatowskich potrzebuje bardzo starannej opieki. Trzeba budzić ducha apostolskiego wśród katolików gorliwych, rozwijać życie eucharystyczne przez krzewienie Komunii św. w pierwsze piątki i soboty miesiąca, otoczyć szczególną pieczą młodzież, dziatwę, zwłaszcza ministrantów i biel, gromadzić parafian na miesięcznych nabożeństwach stanowych, podtrzymywać zbawienną praktykę dobrze zorganizowanych rekolekcji dla starszych parafian, młodzieży i dzieci w oddzielnych grupach"145.

${ }^{144}$ B. Stanaszek, Diecezja sandomierska..., dz. cyt., t. 2, s. 138, 140.

${ }^{145}$ ADS, Akta Wizytacji Pasterskiej 1962-1969, Uwierzytelniony odpis protokołu wizytacji pasterskiej przeprowadzonej 7 VI 1958 r. w parafii Opatów, Opatów, 8 VI 1958 r. Na jednym z zebrań plenarnych PZPR w Opatowie w połowie lipca $1958 \mathrm{r}$. jeden z dyskutantów piętnował niekorzystną sytuację, gdy „Kler posiada fundusze na zakup różnego rodzaju sprzętu sportowego dla młodzieży, pieniądze na zakup sprzętu pochodzą ze składek rodziców. (...) Zachodzi konieczność zajęcia się pracą wśród harcerstwa, gdyż do tej organizacji kler próbuje wsadzać swój nos, a przecież od wychowania harcerstwa zależy przyszła organizacja młodzieżowa. Musimy zorganizować na szczeblu powiatu aktyw do pracy z młodzieżą. Aby kler nie miał wpływu na młodzież zależy od wysiłku nas samych, od naszych członków partii”. APK, KP PZPR w Opatowie, sygn. 34 (65/II/10), k. 107. W podsumowaniu dyskusji stwierdzono: „Nie pozwolimy, aby kler walczył z władzą ludową, uważamy kler jako ośrodek reakcyjny, który liczy na obalenie naszego ustroju kap [przekreślenie w tekście - R.G.] socjalistycznego, są zalecenia odgórne, aby zwracać uwagę na działalność kleru, gdyż ten chce poprowadzić młodzież swoimi drogami". APK, KP PZPR w Opatowie, sygn. 34 (65/II/10), k. 108. Dyskusję wywołał referat pt. „O sytuacji wśród młodzieży i zadaniach pracy partyjnej z młodzieżą”. Referujący ostro krytykował działalność duszpasterską duchowieństwa. M.in. stwierdził: „Nie można w żadnym razie hołdować hasła podnoszonego przez reakcję i kler, że jakoby cała młodzież była zła rzekomo według nich na skutek demoralizatorskiej roli socjalistycznego wychowania, jest to fałsz, obłuda. Takim krytykom socjalizmu i socjalistycznego wychowania trzeba dawać zdecydowaną odprawę. [...] Kler i reakcja próbują nam zarzucać, że socjalistyczne wychowanie deprawuje młodzież, powstaje wobec tego pytanie pod ich adresem dlaczego w tak katolickim kraju jak NRF, rządzonym przez partię z katolickim kanclerzem 
Po upływie kilku lat, 20 czerwca 1964 r. odbyła się następna wizytacja kanoniczna. Biskup Piotr Gołębiowski udzielił wtedy sakramentu bierzmowania dla 1182 osób. Następnego dnia biskup odprawił Mszę św. dla dzieci i młodzieży oraz wygłosił szereg kazań także na kolejnych mszach. Przed odjazdem na miejscowym cmentarzu poświęcił płytę nagrobną dla śp. ks. kan. Stanisława Szczepaniaka, zmarłego w 1962 r. oraz odwiedził klasztor. Ocena życia religijnego parafii Opatów wypadła dobrze. Liczba niedzielnych mszy wzrosła do sześciu. Ponadto odprawiano jedną w szpitalu i cztery w kościele bernardynów. Na ogólną liczbę parafian około 8 tys. w niedzielnych mszach uczestniczyło 4,5-5 tys. W 1963 r. rozdano ogółem w obu kościołach i szpitalnej kaplicy 36260 komunii, co biskup nadal uznawał za liczbę zbyt niską. Biskup zalecał więc odprawianie mszy wieczornej w niektóre dni powszednie oraz upowszechnienie praktyki przyjmowania komunii w pierwsze piątki miesiąca. Generalna ocena religijności brzmiała następująco: „Parafianie opatowscy są przywiązani do wiary św., ale nie odznaczają się większą gorliwością w służbie Bożej, ani ofiarnością na cele kościelne. (...) Coraz częściej rodzice zwlekają z ochrzczeniem dzieci, a co jest boleśniejsze nagminne stają się zabójstwa dzieci nienarodzonych. Pijaństwo jest dość częstym zjawiskiem, kilkadziesiąt par żyje bez ślubu kościelnego. Kilka rodzin należy do sekty «Ś́siadkowie Jehowy»"146.

Największa była skala zaangażowania władz partyjno-państwowych w organizację uroczystości antymilenijnych. Zanim do nich doszło, realizowano dziewięcioletni program Wielkiej Nowenny Tysiąclecia, mający przygotować duchowo wiernych do godnego uczczenia tej ważnej rocznicy. W ramach corocznych inicjatyw Kościoła znalazł się zlot młodzieży w Opatowie 18 maja 1958 r. Zorganizowano go z myślą o zainaugurowaniu obchodów Milenium Chrztu Polski. Frekwencja była bardzo dobra. W zjeździe wzięło udział około dwóch tysięcy osób z dekanatu. Młodzież przybyłą furmankami lub pieszo przyjęli najpierw bernardyni, a w kolegiacie odprawiono dla niej sumę i popołudniowe nabożeństwo różańcowe. Władze UdSW w Warszawie zostały powiadomione o zorganizowaniu zlotu nawet bez złożenia wniosku o zezwolenie u dyrektora WdSW w Kielcach Stefana Jarosza ${ }^{147}$.

Plan ,zabezpieczenia” uroczystości Milenium w Sandomierzu w dniach 1-3 lipca 1966 r. przyjął kryptonim „Wisła”"148. Zalecał on m.in. organizowanie szeregu konkurencyjnych imprez (wyścig kolarski, pokazy wojskowe, akrobatykę motocyklową

na czele, rozmiary szerzącego się huligaństwa [tak w tekście - R.G.] i rozkładu moralnego są daleko większe niż u nas i w ogóle we wszystkich krajach kapitalistycznych, stopień rozwoju huligaństwa i rozkładu moralnego jest w stosunku do krajów socjalizmu, dość wysoki, wynika to z beznadziejności życia jaką niesie ze sobą ustrój kapitalistyczny”. APK, KP PZPR w Opatowie, sygn. 34 (65/II/10), k. 112.

${ }^{146}$ ADS, Akta Wizytacji Pasterskiej 1962-1969, Protokół wizytacji pasterskiej odbytej w parafii Opatów przez J.E. Ks. Biskupa D-ra Piotra Gołębiowskiego 20 VI 1964 r.

${ }^{147}$ B. Stanaszek, Diecezja sandomierska..., dz. cyt., t. 2, s. 309.

${ }^{148}$ B. Stanaszek, Kryptonim „Wisła”. Stużba Bezpieczeństwa wobec obchodów Milenium Chrztu Polski w Sandomierzu, Lublin 2007. 
itd.). Władze oczywiście znały plan najważniejszych uroczystości w Sandomierzu w niedzielę 3 lipca. Samochód z kopią obrazu MB Częstochowskiej - jak początkowo zakładano - miał przybyć z Warszawy 2 lipca o godz. 17. Po drodze około godziny 13. zaplanowany był przystanek w Opatowie, gdzie miało się odbyć krótkie nabożeństwo w kolegiacie. Jednak przebieg uroczystości w innych miastach Polski spowodował trudności w urzeczywistnieniu tego planu i uroczystości w Sandomierzu odbyły się bez peregrynacyjnego obrazu. Owacyjnie powitano natomiast prymasa Stefana Wyszyńskiego, a puste miejsce przeznaczone dla obrazu stało się symbolem krytycznie napiętych relacji państwa z Kościołem. Kontynuacją uroczystości były tzw. małe peregrynacje w poszczególnych miejscowościach. Władze zastosowały wtedy dotkliwe kary wymierzane przez kolegia karno-administracyjne za „nielegalne” przenoszenie dalszych kopii obrazu Czarnej Madonny. W związku z tym mieszkańcy powiatów Opoczno, Opatów i Szydłowiec należeli do najbardziej represjonowanych w województwie kieleckim ${ }^{149}$.

\section{Zakończenie}

Reasumując można stwierdzić, że kondycja duchowa Kościoła w Opatowie w pierwszym dwudziestoleciu po drugiej wojnie światowej wyglądała dość dobrze. Antykościelna polityka władz partyjno-państwowych nie odniosła większych skutków. Wstępne badania pozwalają stwierdzić, że opatowscy katolicy byli mocno związani z Kościołem, choć nie brakowało powierzchowności i niesystematyczności. Problematyka jakości życia religijnego wymaga dalszych badań z wykorzystaniem dokumentacji dotyczącej następnych lat istnienia PRL. Dopiero wtedy i przy odwołaniu się do porównawczych danych, uwzględniających inne środowiska parafialne, będzie można odważyć się na bardziej precyzyjne i pogłębione wnioski.

\section{BIBLIOGRAFIA}

\section{Źródla archiwalne:}

\section{Archiwum Akt Nowych w Warszawie:}

\section{Komitet Centralny Polskiej Partii Robotniczej:}

sygn. 295/VII-259, Stronnictwo Pracy; Kopia pisma R. Zambrowskiego do KO PPR w Bydgoszczy w sprawie Z. Felczaka 12 II 1945; Informacje na temat zjazdu wojewódzkiego SP w Katowicach 24 II 1946 organizowania SP w Łodzi oraz układu sił w kierownictwie SP; Informacje MBP dotyczące sytuacji w SP.

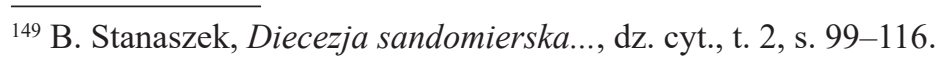


Ministerstwo Administracji Publicznej:

sygn. 671.

Urząd do Spraw Wyznań:

sygn. 31/182.

\section{Archiwum Diecezjalne w Sandomierzu:}

Akta kościoła kolegiaty i parafii w Opatowie (1866-1983).

Akta personalne ks. Andrzeja Glibowskiego.

Akta personalne ks. Stanisława Szczepaniaka.

Akta personalne ks. Tomasza Zadęckiego.

Akta Wizytacji Pasterskiej 1942-1951.

Akta Wizytacji Pasterskiej 1962-1969.

\section{Archiwum Państwowe w Kielcach:}

Komitet Powiatowy Polskiej Zjednoczonej Partii Robotniczej w Opatowie:

sygn. 26 (65/II/2), Protokoły plenarnych posiedzeń KP z załącznikami z 13.02. 22.06 .1950 .

sygn. 34 (65/II/10), Protokoły plenarnych posiedzeń KP z załącznikami z 12.03. 05.11.1958.

\section{Komitet Wojewódzki Polskiej Zjednoczonej Partii Robotniczej w Kielcach:}

sygn. 54/IV-9, Protokoły z posiedzeń Egzekutywy KW PZPR w Kielcach (1950).

sygn. 54/VI-24, Wykaz obiektów sakralnych i kościelnych wzniesionych w woj. kieleckim w latach 1945-1956.

sygn. 54/VIII-204, Protokoły z posiedzeń WZOW (1955).

sygn. 3662, Wydział Ogólny [Bilans Komitetu Wojewódzkiego PZPR w Kielcach za lata 1954-1955].

Urząd Wojewódzki w Kielcach III Wydział do Spraw Wyznań:

sygn. 214, Opatów - parafia rzymskokatolicka pod wezwaniem św. Marcina (19571987).

\section{Wojewódzki Urząd Informacji i Propagandy:}

Sygn. 36, Sprawozdania sytuacyjne i z działalności Powiatowego Oddziału Urzędu Informacji i Propagandy w Opatowie (1945).

\section{Urząd Wojewódzki Kielecki II:}

sygn. 1385, Sprawozdania sytuacyjne starostów za marzec 1949. 


\section{Biuro Ewidencji i Archiwum Urzędu Ochrony Państwa w Warszawie:}

sygn. $\mathrm{XXX} / \mathrm{D} / 1$.

\section{Źródła drukowane:}

Dokument PZPR o działaniach wobec Kościoła katolickiego w województwie kieleckim w 1953 roku, oprac. G. Miernik, „Studia Kieleckie”, seria historyczna, 1995, nr 1.

Jubileuszowy Rocznik diecezji sandomierskiej 2000, Sandomierz 2001.

Rocznik diecezji sandomierskiej 1948 r., Sandomierz 1948.

Rocznik diecezji sandomierskiej 1952/53 r., Sandomierz 1953.

Rocznik diecezji sandomierskiej 1958 r., Sandomierz 1958.

Rocznik diecezji sandomierskiej 1972, Sandomierz 1972.

Spis Duchowieństwa i parafij Diecezji Sandomierskiej 1939, Sandomierz 1939.

Spis Duchowieństwa i parafij Diecezji Sandomierskiej 1944-1945 r., Sandomierz 1945.

Spis Duchowieństwa i parafij Diecezji Sandomierskiej 1946 r., Sandomierz 1946.

\section{Czasopisma:}

„Kronika Diecezji Sandomierskiej”.

\section{Filmy:}

Ksiądz Jan Trojnar, film z serii „Z archiwum IPN”, TVP 2009.

\section{Opracowania:}

Aparat represji wobec Kościoła w latach 1944-1956, terytorium obecnej diecezji sandomierskiej, red. M. Krzysztofiński, ks. J. Marecki, ks. B. Stanaszek, Kraków 2012.

Bober S., Walka o dusze dzieci i młodzieży w pierwszym dwudziestoleciu Polski Ludowej, Lublin 2011.

Bujak W., Historia Stronnictwa Pracy: 1937, 1946, 1950, Warszawa 1988.

Dudek A., Gryz R., Komuniści i Kościót w Polsce (1945-1989), Kraków 2006.

Fedorowski K., Represje Powiatowego Urzędu Bezpieczeństwa Publicznego w Sandomierzu wobec Kościoła rzymskokatolickiego w latach 1944-1956 - problematyka personalno-organizacyjna, „Studia Sandomierskie” 19 (2012), $\mathrm{nr} 1$, s. $5-180$. 
Gryz R., Państwo a Kościót w Polsce 1945-1956 na przykładzie województwa kieleckiego, Kraków 1999.

Gryz R., Ziótkowski Stanisław (1904-1946), w: Leksykon duchowieństwa represjonowanego w PRL w latach 1945-1989. Pomordowani-więzieni-wygnani, red. J. Myszor przy współudziale J. Żurka, Warszawa 2003.

Konopka H., Religia w szkołach Polski Ludowej. Sprawa nauczania religii w polityce państwa (1944-1961), Białystok 1995.

Konopka H., Konopka A., Leksykon historii Polski po II wojnie światowej 19441997, Warszawa 1999.

Krawczyk A., Pierwsza próba indoktrynacji. Działalność Ministerstwa Informacji i Propagandy w latach 1944-1947, Warszawa 1994.

Sado G., O Polskę biało-czerwona. Ksiadz Stanistaw Domański ps. „Cezary” (19141946), Kielce 2009.

Stanaszek B., Budownictwo kościelne $w$ diecezji sandomierskiej $w$ latach 19451970, „Studia Sandomierskie” 9 (2002), s. 372-473.

Stanaszek B., Diecezja sandomierska w powojennej rzeczywistości politycznej w latach 1945-1967, t. 1, Problematyka personalno-organizacyjna, Sandomierz 2006.

Stanaszek B., Diecezja sandomierska w powojennej rzeczywistości politycznej w latach 1945-1967, t. 2, Duszpasterstwo i laicyzacja życia społecznego, Sandomierz 2006.

Stanaszek B., Kryptonim „Wisła”. Stużba Bezpieczeństwa wobec obchodów Milenium Chrztu Polski w Sandomierzu, Lublin 2007.

Stanaszek B., Nowakowski R., Stownik biograficzny diecezji sandomierskiej XIX$X X$ w, t. 1, $A-G$, Sandomierz 2014.

Stanaszek B., Nowakowski R., Stownik biograficzny diecezji sandomierskiej XIX$X X$ w, t. 2, H-t , Sandomierz 2015.

Szczypta-Szczęch R., Powiatowy Urząd Bezpieczeństwa Publicznego Opatów z siedziba w Ostrowcu Świętokrzyskim wobec Kościoła katolickiego w latach 1945-1955, w: Aparat represji wobec Kościoła w latach 1944-1956, terytorium obecnej diecezji sandomierskiej, red. M. Krzysztofiński, ks. J. Marecki, ks. B. Stanaszek, Kraków 2012, s. 49-140.

Zieliński Z., Kościół w Polsce 1944-2002, Radom 2003.

Żaryn J., Dzieje Kościoła katolickiego w Polsce (1944-1989), Warszawa 2003.

\section{Streszczenie}

Po drugiej wojnie światowej władze komunistyczne w Polsce (Polska Zjednoczona Partia Robotnicza - PZPR) realizowały program eliminacji Kościoła z życia publicznego. W mieście Opatów, należącym do diecezji sandomierskiej, jak 
w zwierciadle widoczny był proces, który wystąpił w całym kraju. W artykule na przykładzie parafii Opatów zaprezentowano relacje między Kościołem katolickim a władzami państwowymi. Polityka laicyzacji i ateizacji społeczeństwa objęła parafię św. Marcina, zakony, szkoły i instytucje. Usunięto naukę religii ze szkół publicznych, redukowano materialny stan posiadania Kościoła, zwalniano zakonnice z pracy w przedszkolach i szpitalach. Służby specjalne i państwowa administracja do spraw wyznań inwigilowały działalność religijną i duszpasterską. Dyskryminacyjnej polityki najbardziej doświadczyli księża, zakonnicy i zakonnice pracujące w parafii Opatów. Antykomunistyczny opór i aktywne życie religijne katolików w tym mieście i okolicznych wioskach spowodowały, że Kościół utrzymał wysoki autorytet moralny i pozycję społeczną.

Słowa klucze: parafia św. Marcina w Opatowie, klasztor OO. Bernardynów w Opatowie, relacje państwo-Kościół, komunizm, polityka antykościelna, laicyzacja

\section{The Church in Opatów Under Communism (1945-1966)}

\section{Summary}

After the Second World War, the communist authorities in Poland (Polish United Workers' Party - PZPR) implemented a program to eliminate the Church from public life. In the city of Opatów, which belonged to the Sandomierz diocese, the process that was implemented mirrored what was occurring throughout the country. In this article, the interactions between the Catholic Church and state authorities is presented using the example of the Opatów parish. Policy of atheism and secularization of society took over the parish of St. Martin's religious orders, schools and institutions. Religious education was removed from public schools, the material possessions of the Church were reduced, and nuns were dismissed from work at kindergartens and hospitals. The secret services and state administration for religious denominations were instituted to oversee religious and pastoral activities. The most discriminatory policy was experienced by priests, monks and nuns working in the Opatów parish. Anti-communist resistance and active religious life of Catholics in this city and surrounding villages meant that the Church maintained a high moral authority and social position.

Key words: St. Martin's parish Opatów, Bernardine monastery in Opatów, state-church relations, communism, anti-church policy, secularization 